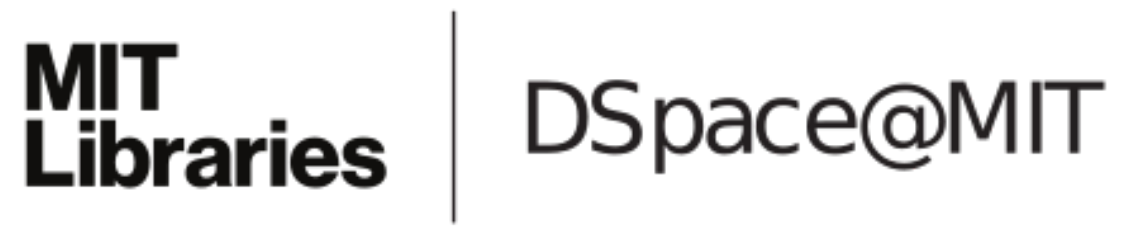

\author{
MIT Open Access Articles
}

\section{Varieties of Urbanism: A Comparative View of Inequality and the Dual Dimensions of Metropolitan Fragmentation}

The MIT Faculty has made this article openly available. Please share how this access benefits you. Your story matters.

Citation: Freemark, Yonah et al. "Varieties of Urbanism: A Comparative View of Inequality and the Dual Dimensions of Metropolitan Fragmentation." Politics and Society 48, 2 (February 2020): 235-274 (c) 2020 The Author(s)

As Published: http://dx.doi.org/10.1177/0032329220908966

Publisher: SAGE Publications

Persistent URL: https://hdl.handle.net/1721.1/128252

Version: Author's final manuscript: final author's manuscript post peer review, without publisher's formatting or copy editing

Terms of use: Creative Commons Attribution-Noncommercial-Share Alike 
Freemark, Yonah, Justin Steil, and Kathleen Thelen. "Varieties of Urbanism: A Comparative View of Inequality and the Dual Dimensions of Metropolitan Fragmentation." Politics \& Society 48.2 (2020): $235-274$.

\title{
Varieties of Urbanism: A Comparative View of Inequality and the Dual Dimensions of Metropolitan Fragmentation
}

\author{
Yonah Freemark (ORCID oooo-0003-3622-6354) \\ Massachusetts Institute of Technology \\ Justin Steil (ORCID 0000-0003-I76I-655X) \\ Massachusetts Institute of Technology \\ Kathleen Thelen(ORCID 0000-0003-4I02-8504) \\ Massachusetts Institute of Technology
}

\begin{abstract}
A large literature on urban politics documents the connection between metropolitan fragmentation and inequality. This article situates the United States comparatively to explore the structural features of local governance that underpin these outcomes. Examining five metropolitan areas in North America and Europe, we identify two distinct dimensions of fragmentation: (a) fragmentation through jurisdictional proliferation (dividing regions into increasing numbers of governments), and (b) fragmentation through resource hoarding (via exclusion, municipal parochialism, and fiscal competition). This research reveals how distinctive the United States is in how it combines institutional arrangements that facilitate metropolitan fragmentation (through jurisdictional proliferation) and those that reward such fragmentation (though resource-hoarding opportunities). Non-U.S. cases furnish examples of policies that reduce jurisdictional proliferation and/or remove resource-hoarding opportunities. Mitigating the inequality-inducing effects of fragmentation is possible, but policies must be designed with an identification of the specific aspects of local-governance structures that fuel inequality in the first place.

\section{Keywords}

Inequality; Fragmentation; Metropolitan Governance; Local Politics; Resource Hoarding

\section{Corresponding author}

Yonah Freemark, Massachusetts Institute of Technology, 77 Massachusetts Avenue, Cambridge, MA 02I39.

Email: freemark@mit.edu
\end{abstract}


Between 2002 and 20I7, the number of local government units in the United States increased by more than $2,500 .{ }^{1}$ Some of these local governments incorporated as new municipalities or seceded from larger school districts to form wealthier, whiter districts. These events are part of a long-standing trend toward jurisdictional proliferation in many metropolitan areas. This trend accelerated in the late $19^{\text {th }}$ and $20^{\text {th }}$ centuries, and especially since the 1970 , as suburbs incorporated to avoid being subsumed within larger cities that featured more socially heterogeneous populations and lower-income households. ${ }^{2}$ Thus, for instance, the wealthy Brookline suburb is surrounded on three sides by the City of Boston, having successfully resisted annexation since I873; University Park, with one of Texas' best-performing school districts, is entirely encircled by Dallas and has tenaciously defended its autonomy since 1945; in the San Francisco Bay Area, Piedmont, once known as the "City of Millionaires," resisted annexation by Oakland in I897 and in 2013 installed cameras with license plate readers at city entry points, purportedly to combat "spillover" crime. ${ }^{3}$ The power to construct and maintain jurisdictional boundaries is frequently deployed by affluent communities to hoard resources at the expense of their less-affluent neighbors. In the words of a leader in an effort to detach three of the highestperforming schools from the county school district that includes Chattanooga, Tennessee, "local control is power."

Major metropolitan areas throughout the rich democracies exhibit patterns of spatial inequality, but the politics of metropolitan fragmentation and the extent to which they entrench or mitigate these inequalities vary widely. Like Boston and San Francisco, the London and Paris metropolitan areas contain a large number of separate jurisdictions. Moreover, a wave of reforms beginning in the I980s delegated significant new powers and responsibilities to these European localities. Sometimes introduced under the banner of "new public management," the British and 
French governments designed these reforms to increase administrative efficiency and enhance local control over service delivery. ${ }^{5}$ This devolution of powers, however, did not unleash the same intense resource-hoarding dynamics that are commonplace in the United States. Indeed, in some cases they inspired actions such as municipal mergers. The words of a French mayor who agreed to join a neighboring city in a new municipality stand in striking contrast to those of the Chattanooga leader quoted above: "we are stronger when we are together."

Across the rich democracies, cities are important sites of political contestation over crucial issues of economic redistribution and social opportunity. The contributions of local politics to national-level differences in inequality and poverty are undisputed. Yet the literature on cities in comparative political economy remains underdeveloped as a result of a continued emphasis on national-level institutions and political dynamics. Meanwhile, although there is a large and rich literature on U.S. urban politics, comparisons to other rich democracies are rare. ${ }^{7}$

This article situates the U.S. case in a comparative perspective to isolate the features of local governance that support the resource-hoarding dynamics that are so characteristic of its local politics - and to identify some of the institutions and the mechanisms through which other rich democracies reduce these dynamics. None of the rich democracies escapes the problems of spatial inequality that characterize metropolitan life, and yet the degree to which municipal boundaries are associated with highly unequal policy packages and public services is particularly pronounced in the United States. Indeed, the strategies commonly deployed by affluent U.S. communities to separate themselves—administratively and fiscally—-from their less affluent neighbors are virtually unthinkable in many other industrialized democracies. A comparative perspective thus offers a fresh angle on the possibilities and pitfalls of local control, providing new insights by allowing us to consider variation in the structure of local governance-varieties 
of urbanism - and the relationship of that variation to metropolitan growth and its inequalitygenerating effects. ${ }^{8}$

We argue that to understand the relationship between local-government structure and economic inequality, metropolitan "fragmentation" must be understood in at least two dimensions and considered separately across multiple policy arenas. ${ }^{9}$ The first dimension of fragmentation (and the common understanding of the term) is the division of a metropolitan area into many municipalities surrounding a central city; we refer to this as jurisdictional proliferation. The ability to form and maintain small jurisdictions is determined by legally defined capacities to incorporate, annex, and secede, as well as by the ability to create so-called special-purpose authorities. Such capacities already distinguish the United States from many of its peers.

Evidence from other advanced industrial countries, however, demonstrates that the number of separate local governments, in and of itself, does not produce inequality. Moreover, examples from abroad suggest that institutional structures can either incentivize jurisdictional proliferation or discourage such municipal boundary-drawing. We show that the returns to jurisdictional proliferation depend crucially on the availability of opportunities for resource hoarding - the second dimension of metropolitan fragmentation. Comparative analysis thus reveals how distinctive the United States is in the way it combines institutional arrangements that facilitate metropolitan fragmentation (through jurisdictional proliferation) and those that reward such fragmentation (through opportunities for resource hoarding).

Comparative analysis also yields new insights into the dynamics through which jurisdictional proliferation and resource hoarding become entrenched — but also how they can be reversed. The U.S. experience suggests that inequality-promoting features of metropolitan 
institutions often deepen gradually through largely hidden processes of change—drift and conversion —as, for example, municipal boundaries are held in place even as populations shift (drift) or as the redrawing of boundaries turns otherwise progressive property taxes into regressive revenue structures (conversion). ${ }^{10}$ Other countries provide examples of measures designed to reverse jurisdictional proliferation or limit its negative impacts. In the cases we consider here, changes to either of the dual dimensions of metropolitan fragmentation have required more overt political reforms, in some cases following a transition in political power, or in other cases, representing a technocratic response to perceived inefficiencies or inequality.

In addressing these issues through a comparative lens, our analysis engages a longstanding debate on the merits of local control. Some scholars take a sanguine view of local governance as way to promote responsiveness by bringing the state "closer" to its constituents, thus improving service delivery and tailoring policy to local conditions. Democratic theorists often stress the benefits of local control for enhancing citizen engagement, particularly engagement among underrepresented groups. ${ }^{11}$ Others emphasize the economic benefits of local control. Mainstream economic theory suggests that subnational economic and political power (such as over taxes and regulations) encourages competition for residents and business which, in turn, promotes optimal allocation of public goods to individuals across municipalities. ${ }^{12}$ Weingast promotes devolution as limiting rent seeking while "credibly commit[ing]" subnational governments to market preservation. ${ }^{13}$

Others, however, point to problems associated with local control. Peterson's foundational contribution proceeds on the assumption that cities share an interest in growth to build tax revenue, but he emphasizes the limits to local redistributive politics because of the movement of people and goods between localities. ${ }^{14}$ Steiner et al. see decentralization as weakening 
governmental effectiveness by inhibiting economies of scale and encouraging parochialism, exclusion, and a race to the bottom among localities. ${ }^{15} \mathrm{~A}$ host of other scholars of American politics have documented how local governing institutions promote inequality and social immobility. For example, Katznelson and, more recently, Hayward, explore the problematic interaction of class, race, and community. Weir contributes insights into the origins and effects of urban-suburban cleavages. Trounstine documents persistent patterns of "segregation by design" that result from the overweening influence of white property owners in local politics. Research by Einstein and colleagues confirms that such interests are overrepresented in planning and zoning-board decisions. ${ }^{16}$ We build on the insights these works offer by leveraging cross-national and over-time comparisons to highlight the distinctiveness of U.S. local-governing institutions and to identify the mechanisms through which other rich democracies have avoided (or at least reduced) the resource-hoarding dynamics that these scholars have identified as so problematic.

Our objective in this article is primarily conceptual— to develop a framework for systematically comparing local-governance structures that exacerbate or mitigate space-based inequality. The framework is designed to capture key differences across the rich democraciesincluding both broad cross-national differences as well as variation within countries that feature significant subnational variation on the dimensions we identify. The framework assumes formal rules and a robust enforcement regime. It thus may not extend to developing countries that feature high levels of informality, though we do not rule out the possibility of adapting it to other contexts.

Within the parameters of these scope conditions, we sought out cases that might shed light on distinctive features of local governance in the United States. In the comparative literature, the United States is considered the paradigmatic case of a "liberal market economy," 
typically contrasted with Europe's "coordinated market" economies. ${ }^{17}$ We chose France as an example of the latter but we also wanted to identify differences (if any) between the United States and other liberal market economies—-selecting Canada and the United Kingdom as "most similar" on that dimension. Furthermore, our cases include both unitary (France, United Kingdom) and federal systems (Canada, United States). They also capture potentially important features of the legal system - with France based in a civil law tradition versus a common law tradition in Canada, the United Kingdom, and the United States.

Because most observers agree that problems of metropolitan inequality are particularly acute in the most rapidly growing agglomeration hubs of the new "knowledge economy," our analysis focuses on cities that are at the forefront of economic growth. ${ }^{18}$ We examine the Boston, London, Paris, San Francisco, and Toronto metropolitan areas - all large, wealthy, and socioeconomically diverse regions. This selection reflects a mix of "old" economic centers of activity (Boston, London, Paris) and "new" hubs of economic activity and growth (San Francisco, Toronto). Today, all five of these are important hubs of the knowledge economy, registering high rates of economic growth fueled by significant investment in technology. As one measure, we note that London, Paris, San Francisco, and Toronto each attract the largest share of venture capital in their respective countries, and Boston comes in third for the United States, behind San Francisco and nearby San Jose. ${ }^{19}$ The two US metropolitan areas (Boston and San Francisco) chosen for analysis differ from each other on a number of dimensions - east versus west coast, and significant municipal power versus significant county power, respectively. Both, however, are notable for sustained increases in housing costs, often seen as a contributor to the kinds of spatial inequality we are interested in studying. 
We concentrate on municipal power, focusing less on the substantial roles of specialpurpose governments. ${ }^{20}$ Although we touch only briefly on cross-city variation within each country, our framework can be deployed to explore within-country variation as well. We readily acknowledge that the local governance structures (and specifically planning-related issues) that we explore are only one part of the story. A full account of the impact of local politics on inequality would clearly have to consider other variables as well, most importantly the impact of race and white supremacy—a subject on which a large and rich literature exists, including important studies by Allen, Gay, Hochschild, King and Smith, and Soss and Weaver, among many others. ${ }^{21}$ Nevertheless, we believe that this research brings a new comparative perspective to the governance structures of cities in North America and Europe, adding depth to our understanding of the mechanisms, causes, and consequences of urban inequality.

The rest of this article proceeds as follows. We begin by laying out our conceptual framework to map what we call the varieties of urbanism. We identify two distinct dimensions of metropolitan fragmentation: one, the division of urban regions into increasing numbers of governments through jurisdictional proliferation, and two, the institutional structures that enable jurisdictional boundaries to generate inequality-increasing resource hoarding, through three mechanisms: exclusion, municipal parochialism, and fiscal competition. We then illustrate this framework's utility and the distinctions it draws through a consideration of both dimensions of fragmentation across the five metropolitan cases. This section explores how these dimensions work in the context of the key urban-policy issues of municipal incorporation, land use, education, and taxation. The third section then turns from comparative statics to explore the dynamics through which fragmentation along both dimensions either deepens, or can be reversed, again with reference to the experience of our case studies. A final section draws out the 
lessons this research holds for understanding distinct patterns of spatial inequality and identifies several policy implications.

\section{Varieties of Urbanism in the Rich Democracies: A Comparative Framework}

The role of metropolitan fragmentation in promoting inequality is intimately bound up in possibilities for opportunity hoarding, or what Reich has called "the secession of the successful. ${ }^{22}$ To give an example in the present context, residents of a locale use incorporation to draw boundaries around a specific geographic area and those who reside there. Incumbent residents limit entry into the area through zoning that allows only large-lot, single-family homes, and thus admit only wealthy inhabitants. This jurisdiction then "hoards" property-tax revenues, which, were they collected by metropolitan-scale entities, could be redistributed for broader needs. In the process, place-based "opportunities"- such as well-financed and high-performing schools, well-tended parks, safe streets, and other public goods — are denied, or at least made less accessible, to people in nearby jurisdictions. ${ }^{23}$ Given opportunity hoarding's benefits (for some), those who hoard have an incentive to entrench the structures that protect these practices. The result is self-reinforcing, path-dependent inequality: some jurisdictions benefit from extensive services while others continue on the edge of survival. From this perspective, metropolitan inequality is produced by historical sequences informed by contingent effects that are selfreinforcing and difficult to alter, and that lock in suboptimal outcomes. ${ }^{24}$

There are two dimensions of fragmentation at work here- the boundary drawing itself and the restriction of access to valuable resources. These two dimensions, while often empirically related, are analytically separate. To the extent that people of varying socioeconomic statuses can move freely between municipalities and access jobs or housing at their 
skill and income levels, the relationship between proliferation of jurisdictional boundaries and inequality is attenuated. Moreover, if services, such as schooling and police, are provided by metropolitan or national organizations, not local ones, the relative benefits of living in a specific jurisdiction are lessened and thus consequences for socio-economic mobility are diminished. Finally, the extent to which local taxes or other revenues must be shared and redistributed, such as at the metropolitan or state level, shapes the effectiveness of attempts to hoard local resources. In at least these three ways, the motivation and ability to engage in opportunity hoarding may be curtailed if the institutional context changes, independent of municipal boundaries.

Given the analytical independence of these two dimensions of fragmentation, the creation of jurisdiction-spanning metropolitan institutions alone, though often advanced as the principal fragmentation-limiting mechanism, may not reduce inequalities. In fact, metropolitan planning organizations in the United States often reinforce inequality by directing resources to wealthier suburbs rather than to under-resourced central-city or inner-ring-suburban neighborhoods, reflecting the prevailing balance of power within these organizations. ${ }^{25}$ In their examination of "fragmented regionalism," Savitch and Adhikari argue that a "regional paradox" is at play in U.S. metropolitan areas; the role of autonomous local governments continues to expand, even as those governments delegate the governance of certain policy areas to metropolitan-scale singlepurpose authorities. ${ }^{26}$ Middle- and upper-class jurisdictions seek to preserve land values and resulting revenues by maintaining local exclusionary powers in some policy realms (such as housing or education), even as they recognize the benefits of regional cooperation on other matters (such as transportation). This paradox reinforces inequality, since it provides the infrastructure needed to grow the regional economy without threatening the ability of wealthy areas to close themselves off from funding redistributive measures or from becoming more 
economically, socially, racially, or ethnically diverse. Such mechanisms "externalize" the governance of particular policy areas that are auxiliary to the enforcement of local exclusion.

Figure I is a visual representation of the five case-study areas across the two dimensions of fragmentation we have identified. On the $\mathrm{X}$ axis, we represent the relative jurisdictional proliferation of each of the regions, using a Herfindahl index of population distribution across local governments as the defining metric. From left to right, we illustrate regions that are more to less centralized in terms of the distribution of population across separate municipalities. The $\mathrm{Y}$ axis captures the existence of opportunities for resource hoarding, operationalized here in the relative position of each of the regions on an average of measures of three mechanisms through which such hoarding can occur-exclusion, parochialism, and fiscal competition, all presented in more detail below (Tables I through 3). Regions closer to the top of Figure I offer higher rewards for boundary setting than those closer to the bottom. ${ }^{27}$ The figure itself already highlights the distinctiveness of U.S. local government institutions in the way in which they combine high jurisdictional proliferation with high opportunities for resource hoarding. As elaborated in the next section, the Canadian and European regions exhibit lower levels of metropolitan fragmentation, either by forestalling jurisdictional proliferation or by limiting the rewards associated with such boundary-drawing or both. 


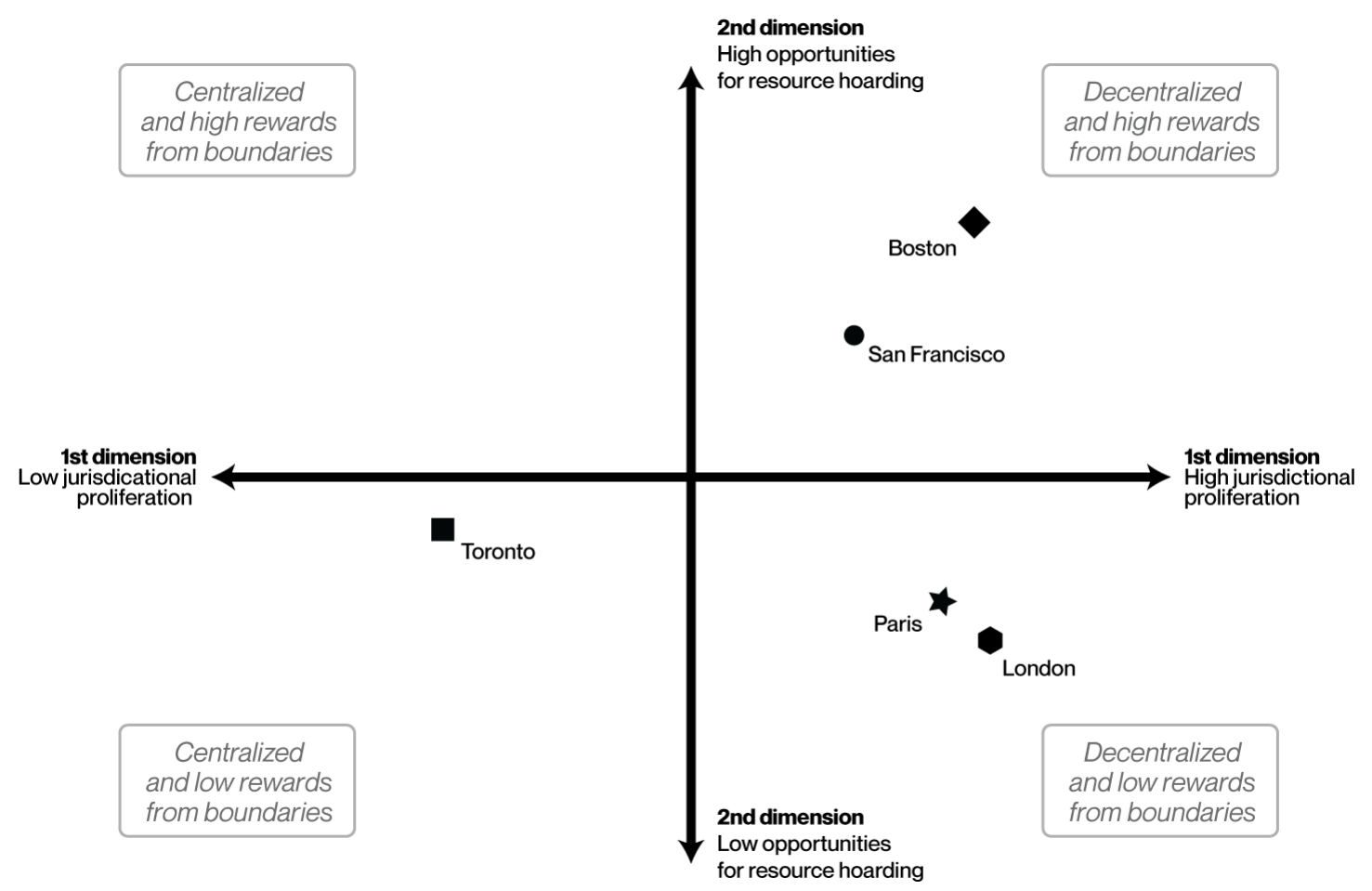

Caption: The dual dimensions of fragmentation.

Source: The authors.

It is worth noting here that none of the cases in our study occupy the top left quadrant of the figure, where regions would simultaneously exhibit a low level of jurisdictional proliferation on the first dimension while also offering high opportunities for resource hoarding on the second. We consider this quadrant to be "unstable"-i.e., empty as an empirical matter because logically the two dimensions in combination (high rewards to boundary setting in the context of high centralization) produce intense pressures to move toward increased jurisdictional proliferation (thus toward the upper right quadrant) unless expressly prevented by higher-level authorities (which would represent a move toward the lower left quadrant). As an example, consider Houston. In 1960, the city of Houston accounted for 75 percent of its metropolitan area's population, but by 2010 this had dwindled to just 35 percent. ${ }^{28}$ Although Texas has relatively 
liberal (compared to most of the United States) annexation powers that encourage localgovernment centralization, continued metropolitan growth combined with high rewards to boundary setting have led individuals seeking to hoard resources to incorporate independent jurisdictions on the city's outskirts (which, once incorporated, cannot be annexed into the central city as easily as unincorporated land). Thus, as the Houston metropolitan region has grown to become the fifth largest in the United States, it has moved steadily from the top left quadrant to the top right. This trend mirrors the shift that occurred in the Boston and San Francisco regions a century ago.

\section{Case Studies in Metropolitan Fragmentation: The United States in Comparative Perspective}

The processes for local-government creation and the delineation of their powers are established through legal frameworks set out at either the national level (e.g. the United Kingdom and France) or the subnational level (e.g. states in the United States and provinces in Canada). These rules, setting out the processes through which municipal boundaries are drawn and changed as well as the scope of municipal powers, vary significantly cross-nationally as well as within some countries from region to region.

\section{First dimension of fragmentation: Jurisdictional proliferation}

On the first dimension of fragmentation, through jurisdictional proliferation, localism in the United States shares some similarities with European counterparts. In fact, among the cities considered here, Toronto is an outlier for its high level of centralization. Through much of the nineteenth century, many U.S. cities expanded through annexations and consolidations. Such 
expansions were often initiated by state legislatures, or they occurred through legal arrangements that counted the larger number of ballots from annexing cities together with the fewer ballots from areas to be annexed. These annexation structures have persisted in some Southern and Western states, supported, among other reasons, by a desire for governmental efficiency. In the majority of states, however, annexation by central cities of surrounding communities effectively ended nearly a century ago, as suburban municipalities incorporated as separate entities, grew in power, and then blocked city expansion. ${ }^{29}$

Most U.S. states now have legal frameworks that facilitate the separate incorporation of new municipalities and that hinder annexation of smaller municipalities by larger ones. Incorporation of suburban areas into distinct, general-purpose governments typically requires only a majority vote of the residents in the areas to be incorporated. ${ }^{30}$ In most states, residents of neighboring communities or central cities play no role in the incorporation process, despite the impact such changes may have on them, e.g., by siphoning off tax revenues that otherwise would be available for city-wide redistribution. ${ }^{31}$ By contrast, annexation often requires support of a majority or super-majority in both the annexing municipality and in the areas to be annexed (individually). Moreover, the number of states requiring popular referenda in areas targeted for annexation has increased over the past three decades. ${ }^{32}$ American cities have long faced tenacious resistance from suburbs resisting annexation because of the higher tax rates central cities typically levy in order to meet regional needs and to support a generally lower-income population. ${ }^{33}$

Both Boston's and San Francisco's boundaries have remained unaltered for over a century despite dramatic population change, and neither has any overarching, general-purpose metropolitan government. San Francisco has been a consolidated city and county (with no 
change in land area) since I856, despite a 6o-fold increase in the Bay Area population since then. In that region, there are nine counties and about Ioo municipalities (governed under home-rule doctrine) that generally control local roads, policing, and land-use decisions. ${ }^{34}$ School districts, though funded with significant support from the state of California, match municipal or county boundaries, depending on the grade of education provided, with elected school boards independent from those general-purpose local governments. Transit is provided through an amalgam of offerings from counties (such as San Francisco Muni and the East Bay's AC Transit) and metropolitan agencies (such as BART, which has an independently elected board with members from three counties, even though the system now extends into two additional counties where voters have no direct input into network management as a whole).

Despite a high level of economic interdependence across the greater San Francisco metropolitan area, there is no regional general-purpose government in the Bay Area. The Association of Bay Area Governments acts as a council of governments, and does provide a forum in which municipal and county officials discuss land use, housing, and environmental planning. The Association's staff merged with that of the Metropolitan Transportation Commission in 20I9, and the two organizations have even developed a joint land-use and transportation plan. Yet this plan only provides a "roadmap" for regional initiatives; it does not prescribe and cannot overrule local land-use or transportation investments.

Boston's boundaries have been fixed since I9I2, even as the population of the metropolitan area has doubled. This region is comprised of seven counties (with almost no independent powers) in two states (Massachusetts and New Hampshire), as well as 198 municipalities that control and finance local roads, land-use planning, police, and schools (although there is a state school-funding "floor"). ${ }^{35}$ As in the Bay Area, most Boston-area 
municipalities have home-rule charters that specify each city's role and powers, policy jurisdiction, and institutional configuration. Each charter must be approved by the state, meaning that the city of Boston has different powers than adjacent Cambridge or Somerville, for example ${ }^{36}$ Home-rule charters do not protect local governments from having policies preempted by state legislation, and municipalities in both Massachusetts and New Hampshire must secure state legislative authorization for entry into many new policy realms. ${ }^{37}$

Similar to San Francisco, the Boston region has no general-purpose metropolitan government. The Metropolitan Area Planning Council and the Boston Region Metropolitan Planning Organization play roles in developing land-use and transportation plans to meet federal guidelines, and the state of Massachusetts controls highways and the transit system. Yet none of these overarching planning bodies is able to determine local land uses or overrule locally financed roads projects. Public housing is managed by individual municipalities, in compliance with federal regulations, but tax-credit funds for the development of new affordable housing are distributed by the state government to private developers.

In Europe and Canada, jurisdictional proliferation and small-area local governments are also common. In the London region, the 32 boroughs and City of London, the region's historic center, form the lowest level of local control. These municipalities are run by ward-based councils elected by residents (in the City, business representatives can also vote), and they control local roads, environmental issues, some social housing, and most elementary schools, among other competencies. Borough boundaries are fixed, and indeed all English land is incorporated, which effectively precludes any annexation or new incorporation. Throughout the country, county councils act as "upper-tier" local authorities with responsibility for service delivery. These councils operate as metropolitan institutions just below the national government. 
Thus, the London County Council provided limited metro-wide coordination for the entire period from I899 to 1965 , before being replaced by the even more encompassing Greater London Council (GLC).

Metropolitan-level governance suffered a temporary setback in 1985 when Prime Minister Margaret Thatcher abolished the GLC as a way of silencing its leader, a vocal left-wing critic of her government's austerity policies. "Red Ken" Livingstone had used his platform as head of the GLC to draw attention to the negative impact of Thatcher's economic programs, for example, by posting a billboard of London's rising unemployment figures on the front of County Hall directly across the Thames from Parliament. Between 1985 and I999, the GLC's powers were devolved largely to the London boroughs, and the County Hall itself was sold to an entertainment company. However, soon after the Labour Party returned to power in 1997, the new government acted on the results of a popular referendum and in 1999 established a new overarching governance structure - the Greater London Authority (GLA) — to set out the strategy for the region.

The GLA consists of an assembly with members elected partly at large, partly by ward, headed by a popularly elected mayor (the first to be elected was Ken Livingstone himself, who began his inaugural address with the words: "As I was saying when I was so rudely interrupted I4 years ago" ${ }^{38}$ ). The GLA does not directly provide or regulate services in health, education, land use, or environmental protection, but the Mayor is charged with statutory responsibility to coordinate public sector action for the entire area. Thus, while land-use powers remain largely within the control of the boroughs, the Mayor is required to produce a spatial development strategy, known as the London Plan, and the GLA has the power to intervene in land-use applications submitted to individual boroughs that the GLA deems to be of strategic importance. 
These applications generally apply to projects that would involve more than 150 residential units, would be over 30 meters tall, would affect more than one borough, or would have a significant impact on the implementation of the London Plan. The metro-wide authority is also empowered to establish Mayoral Development Corporations for specified areas, and the Mayor is further required to establish an overarching housing strategy for the metropolitan area. He or she controls funding allocated from the national Homes and Communities Agency, and directs a Housing Corporation that has powers to acquire land and develop social housing.

Despite its considerable powers, the GLA's role as a metropolitan-level local government can sometimes be ambiguous because of the lack of clear accountability in the two-tier governance structure that it represents. In particular, the Mayor of London remains at the mercy of borough councils for many decisions affecting questions of housing placement and future land uses. ${ }^{39}$ At the same time, however, individual boroughs are constrained by the overarching metro-wide governance structures just described, as well as by national-level institutions that impose a degree of uniformity across separate jurisdictions. For example, education funding is provided by the national government and distributed on a per-pupil basis. ${ }^{40}$ National statutes establish the parameters for the policies pursued by each level of government, and local powers are generally common among adjacent municipalities under the same code. ${ }^{41}$

France as a whole features a higher degree of first-dimension fragmentation than the United Kingdom, and, in 2015, France alone accounted for a third of all municipal governments in Europe. The entire country is organized into communes (municipalities); as in the United Kingdom, there is no potential incorporation or annexation of unincorporated land. The French governmental hierarchy is roughly standardized across the country. Municipalities are governed by popularly elected proportional councils that, alongside other competencies, typically oversee 
local roads, land-use planning, and social housing distribution. Départements (counties) have ward-based popularly elected legislatures, and regions have popularly elected proportional legislatures. The city of Paris is both a municipality and a county and, like Lyon and Marseille, has neighborhood-based voting for local elections. The Parisian suburbs are divided into seven counties in the Île-de-France region, which manages and funds most of the transportation network. The national government controls and funds most policing and education. ${ }^{42}$

The French state is historically associated with a high degree of centralization and this was clearly one aim of the 1958 constitution of the Fifth Republic. Despite this reputation, French municipalities came to command considerable powers over the course of the I970s as local officials carved out room for greater autonomy in economic and social affairs. ${ }^{43}$ The process was facilitated by strong connections between local and national-level political elites. French politicians often use local political office-holding to build a national reputation (five of the eight Fifth Republic Presidents served previously as mayors), and members of the National Assembly have until recently often simultaneously remained in their posts at the local level. This constellation supported competition among local leaders to win recognition by promoting development for their cities, especially in the late I970s as newly-elected Socialist mayors sought to establish themselves as reliable stewards of economic growth. The 1982 Decentralization Act, passed in Socialist President François Mitterrand's first term, formalized these trends. The Act gave local governments direct control over land-use planning and building permits, reducing the influence of national government prefects—-who previously had exercised tutelle control over local governments (meaning they managed their affairs) - to a role of enforcer of national laws in the context of more significant local autonomy. ${ }^{44}$ 
Importantly, however, local officials wishing to enhance their national reputations were also held accountable for welfare and social cohesion within their jurisdictions. ${ }^{45}$ Indeed, the retreat of the central state from its previous coordinating functions inspired increased bottom-up cooperation across French municipalities by compelling local officials to develop their own expertise and administrative infrastructure. ${ }^{46}$ Subsequent national legislation—-the Chevènement law, passed in 1999 under the socialist government of Lionel Jospin — underwrote these trends by encouraging municipalities to coordinate service provision through intercommunal cooperative institutions, which (as of 20I8) cover all but four French municipalities. The institutions are led by representatives of constituent municipalities; they have the capacity to levy their own taxes and provide services. A more recent national reorganization created a new structure to encourage larger-scale regional collaboration by creating metropolises, i.e., large intercommunal agreements, to replace previous structures. In the Paris region, the Métropole du Grand Paris encompasses about 60 percent of Île-de-France's population. The Métropole du Grand Paris is divided into I 2 intercommunal cooperative territories, which take on several service-provision, planning, and development functions. The national government has encouraged communal mergers and the number of communes in France fell by almost I,700 between 2015 and 2018 (compared to roughly 36,500 total communes in 2014). ${ }^{47}$

Ontario, like Canada generally, but unlike England and France, has unincorporated land. In the Toronto region, however, all land is municipalized. The City of Toronto is just below Ontario in that province's governmental hierarchy, and encompasses about half of the metropolitan area's population. Its present boundaries were established by provincial legislation in 1998 , when the then-conservative Ontario government forced a merger of the historic city with five neighboring suburbs. In the years leading up to the amalgamation, the richer City of 
Toronto- through the structure of an overarching Municipality of Metropolitan Toronto-had subsidized the "booming but tax-poor" suburbs. ${ }^{48}$ As the suburbs grew wealthier, the residents of the city core began advocating the abolition of the Metro layer of governance under the banner of enhancing local democratic control. Ignoring such appeals, as well as the results of a non-binding referendum in 1997 across all the affected jurisdictions ( 76 percent of voters were against amalgamation), the Ontario government proceeded with the merger, among other justifications, to eliminate "duplication and waste" and to enhance Toronto's position in the "global market place." ${ }^{\prime 9}$ The effect of the 1998 Amalgamation was to reduce inner-city autonomy, creating a "megacity" that empowered social conservatives from suburban areas who drowned out the more progressive vote of the historic city in what one observer called a "suburban ambush."

Toronto thus now exhibits a much higher level of centralization than any of the other metropolitan regions considered here, with a strong, directly elected mayor and a ward-based council that manages local roads, a portion of the transit system, and local policing. The province, however, continues to control the regional transit agency and distributes equal school funding for students through four provincial-level school systems. ${ }^{51}$ Other sections of Ontario are either "single-tier" municipalities (e.g. Hamilton, similar in power to Toronto), or "two-tier" municipalities, in which there is a lower-tier local government and an upper-tier "regional municipality." These regional municipalities act as metropolitan governments; the power each holds is roughly standardized across the province.

The cases of London and Paris - where levels of formal jurisdictional fragmentation are comparable to Boston and San Francisco-demonstrate that a large number of separate local governments does not, in and of itself, generate identical levels of inequality; instead, the level of inequality depends also on the existence (or not) of overarching coordinating structures. 
Conversely, Toronto - the outlier among the cases in its level of centralization - shows that firstdimension consolidation is not necessarily always inspired by egalitarian motives. Thus, firstdimension fragmentation may be a necessary precondition for the growth of space-based local inequality, but alone it is insufficient to explain unequal metropolitan outcomes. Instead, the most significant sources of local inequality are derived from the ways in which jurisdictional proliferation combines with opportunities to leverage local control to capture and hoard resources at the expense of neighboring communities.

\section{Second dimension of fragmentation: Resource hoarding}

The second dimension of fragmentation captures the potential for using jurisdictional boundaries to hoard resources. We consider three mechanisms through which such resourcehoarding can occur: exclusion through barriers to entry, as articulated through land-use planning and housing policy; municipal parochialism as expressed through school funding; and fiscal competition through taxation and redistribution policies. These areas are all key to communities' ability to hoard resources, as they define what can be built, who can reside there, and how resources are obtained and distributed for local services.

\section{Exclusion through barriers to entry: Land-use planning and housing policy}

In the United States, the structure of local government allows cities to erect multiple barriers to entry that exclude lower-income households. ${ }^{52}$ Zoning is a key exclusionary mechanism for some municipalities. Across the United States, land development is not usually directed toward meeting goals mandated by broader metropolitan or state-level plans (many do not even have such plans), nor are municipalities generally required to meet state-level goals, such as achieving a minimum level of affordable housing. ${ }^{53}$ Instead, local control often means 
governments allocating a large share of developable land within their boundaries for the construction of single-family homes rather than multi-family development, through what is sometimes called fiscal zoning, in order to maintain high property values and property tax revenues, and to reduce demands for public services. Even large cities undertake this approach; of the land within the City of San Francisco on which residential uses are allowed, 49 percent has been zoned to permit only single-family units. ${ }^{54}$

The absence of institutionalized connections between regional planning and local zoning makes metropolitan-area policy in the United States exceptional compared to the other regions studied. Massachusetts is rare among states in allowing affordable-housing developers whose planning-related permits are denied by local governments to appeal to state courts if that locality does not already have ten percent of units designated as affordable (Massachusetts General Laws Chapter 40(b) $\S \S 20-23$ ). Nevertheless, only I9 percent of municipalities in Massachusetts (67 of 35I) have met the ten-percent threshold since Chapter $4 \mathrm{O}(\mathrm{b})$ was enacted in $1969 .{ }^{55}$ California has more robust planning requirements than other states, but still gives localities discretion over most zoning. State law requires local governments to plan to meet the housing needs of all residents, including low-income families, but these planning goals are not robustly enforced and have yet to translate into anything approaching equitable access to subsidized housing across the state or its regions. ${ }^{56}$

By contrast, each of the Canadian and European regions considered here has developed legal regulations that hinder the spatial exclusion of low-income individuals (see Appendix A for a summary of the differences in land-use powers across our cases). In the London, Paris, and Toronto regions, growth plans established by higher levels of government (either national or regional) are implemented through legally binding land-use or equivalent development 
requirements. Local governments formally control zoning, as in the United States, but that control is considerably attenuated by the institutionalized role of higher-level stakeholders.

In England, the national government has nationalized all land-development rights under the Town and Country planning system. An overarching National Planning Policy Framework sets out the framework within which local housing and development plans must operate, including expectations regarding affordable housing development for major developments. The U.K. government runs a Planning Inspectorate, allowing appeals of plans or development projects to align them with local, regional, and national plans ${ }^{57}$ For the London region specifically, the GLA establishes goals for the metropolitan area. ${ }^{58}$ The most recent version of this "London Plan" includes such elements as a 35 percent affordable-housing requirement for many private housing developments, with a goal of 50 percent of units designated as affordable. The boroughs and the City of London work out how to attain specific housing production and affordability goals in accordance with the London Plan's overarching mandates. ${ }^{59}$ The Mayor of London oversees and can veto major projects pursuant to the London Plan, and can also reject or amend borough plans.

A similar hierarchy is enforced in France. Three national laws - all passed in the last two decades - are particularly important in requiring regional and local plans to address environmental and affordable housing requirements. The Grenelle I (2009) and II (20I0) laws include measures to prevent environmental degradation. The Urban Solidarity and Renewal Law (passed in 2000; extended in 20I3) requires municipalities to provide 25 percent affordable housing locally by 2025. In the interim, local governments must either demonstrate progress toward achieving that goal, or pay significant fines from their local budgets. ${ }^{60}$ The prefect (the national-government representative) may employ eminent domain and national housing funds to 
acquire land and build affordable housing in municipalities that do not meet the 25 percent requirement. In the Paris region, public organizations — city subsidiaries, intercommunal institutions, or the national government—develop almost one third of housing units through control of large land parcels; as such, they have additional power to construct affordable housing. Policies in the Île-de-France regional plan must be incorporated into municipal plans and plans developed by intercommunal institutions. When it created the Métropole du Grand Paris, the government also mandated that this new overarching authority merge each local plan into a unified document, which itself is subject to the still more-encompassing regional plan. Local plans incorporate zoning and thus directly link the policy goals of the national and regional governments to on-the-ground development requirements. ${ }^{61}$

The Canadian national government has a minimal role in local land-use, but provincial governments have significant authority over municipal outcomes. The Ontario government has developed several regional plans. These include the Growth Plan (2017), which specifies minimum zoning levels around transit stations; the Greenbelt Plan (2017) which protects agricultural land, heritage sites and natural habitats; and the Provincial Policy Statement (2014), which provides a comprehensive set of land use planning goals. These plans, like the London Plan and the Île-de-France Plan, are mandatory in that they must be reflected in municipal plans. In order to enforce the primacy of the provincial-level plans, a Local Planning Appeals Tribunal determines whether local plans are in accordance with the provincial plan, and the Tribunal can require alterations if they are not. ${ }^{62}$

All these arrangements contrast starkly with those in the United States, where municipalities do not have to dedicate funds for affordable housing and most lack subsidiaries with the power and capacity to orchestrate large projects. Local public housing authorities 
continue to manage units that were mostly created in the immediate post-war period, and the number of public housing units nationally has declined by 26 percent between 1990 and $2017 .{ }^{63}$

The consequences of these varying approaches to regulating land use and development, and the resulting erection or removal of barriers to entry for potential residents, can be illustrated in terms of the concentration of subsidized affordable housing. Table 1 compares the four casestudy regions for which data are available on this measure ${ }^{64}$ In the Boston area, nearly nine out of ten publicly subsidized units are located in just one quarter of the region's cities (compared to less than half of overall housing units). In the Bay Area, nearly three out of four publicly subsidized units are in just one quarter of municipalities (compared to 52 percent of overall housing units).

By contrast, access to subsidized housing is distributed more evenly across municipalities in the London and Paris regions. This is most clearly indicated by comparing their concentration of subsidized housing units versus their concentration of overall population, as shown with Herfindahl scores in the rightmost columns of Table 1. Less than a quarter of each metropolitan area's subsidized affordable units are located in the top 10 percent of municipalities (boroughs in the case of London) and just more than half (Paris) or less than half (London) of subsidized units are in the top 25 percent of cities or boroughs within each respective metropolitan area. Although San Francisco's subsidized-housing Herfindahl score is much lower than Boston's, it concentrates far more housing in the top quarter of metropolitan cities when compared to London and Paris, and its affordable units are much more concentrated than is its population. ${ }^{65}$

Toronto, for which we were unable to acquire full municipal-level data (and therefore have not included in the table), appears close to conditions in U.S. regions in terms of affordablehousing concentration. As of 2000, more than three-quarters of the region's social-housing stock 
was located in the city of Toronto, despite less than half the region's population living there. In this case, however, conditions may be changing; by 2018, the city's share of subsidized private units had declined to 60 percent. $^{66}$

Table 1: Distribution of subsidized affordable housing units by region (2016)

\begin{tabular}{l|ll|l|l} 
& \multicolumn{2}{c}{$\begin{array}{c}\text { Distribution of subsidized affordable } \\
\text { housing units }\end{array}$} & \multicolumn{2}{c}{$\begin{array}{c}\text { Herfindahl index } \\
\text { of concentration }\end{array}$} \\
\cline { 2 - 5 } & Top 10\% of cities & Top 25\% of cities & $\begin{array}{l}\text { Subsidized affordable } \\
\text { housing units }\end{array}$ & Population \\
\hline $\begin{array}{l}\text { Boston region } \\
\text { San Francisco } \\
\text { region }\end{array}$ & $73 \%$ & $87 \%$ & 0.22 & 0.02 \\
$\begin{array}{l}\text { London region } \\
\text { (GLA by borough) }\end{array}$ & $21 \%$ & $73 \%$ & 0.09 & 0.04 \\
Paris region & $24 \%$ & $42 \%$ & 0.04 & 0.01 \\
\hline
\end{tabular}

Note: Definition of affordable housing based on location. Boston and San Francisco: federally supported lowincome units through the public housing, project-based Section 8, Section 202, Section 236, Section 811, and LowIncome Housing Tax Credit programs. London: rented from local housing authority or housing association. Paris: units classified as fulfilling Urban Solidarity and Renewal law guidelines. Sources: U.S. Department of Housing and Urban Development (HUD), “Assisted Housing: National and Local” (2017); HUD Low-Income Housing Tax Credit Database (2016); U.K. Office for National Statistics, “Housing Tenure by Borough” (2016); Observatoire du Logement Social en Île-de-France, “Socle de données à destination des collectivités” (2016).

\section{Municipal parochialism in education funding}

The ability of municipalities to offer a unique set of public goods that distinguishes them from their neighbors is another form of second-dimension fragmentation, and here, too, we find that U.S. cities diverge dramatically from their European and Canadian peers. Public schools are often identified as both a reflection and a driver of jurisdictional proliferation in the United States. Given comparatively high poverty rates and low test scores in many central-city districts, wealthier and typically whiter families often choose to move with their children to other parts of the region. ${ }^{67}$ Indeed, in some cases they even create new, exclusionary school districts in the process. ${ }^{68}$ This produces what we refer to as "municipal parochialism," as local governments distinguish themselves, for instance, by promoting their schools as particularly high-scoring and 
well-funded. Such distinctions are so common and valuable only because the institutional environment allows cities to generate their own schooling funds and permits wide variation across districts in school performance.

Table 2 illustrates how school districts are funded in the five case-study regions. What is immediately apparent is that cities in the United States are highly reliant on local funds to support their schools. In Boston and San Francisco, 70 percent or more of public secondary school funding comes from local sources, overwhelmingly local taxes. By contrast, London, Paris, and Toronto are far less reliant on local funds, since the lion's share of school financing comes from national (France and the United Kingdom) or provincial (Ontario) governments. ${ }^{69}$ The appeal of living in one particular municipality versus another declines where overarching institutions reduce opportunity hoarding and ensure a more equitable distribution of education funding and services. 
Table 2: Sources of funding for education

\begin{tabular}{l|lll} 
& $\begin{array}{l}\text { National } \\
\text { government }\end{array}$ & $\begin{array}{l}\text { State or regional } \\
\text { governments }\end{array}$ & Local governments \\
\hline Boston (city) & $5 \%$ & $25 \%$ & $70 \%$ \\
San Francisco (city) & $5 \%$ & $24 \%$ & $71 \%$ \\
$\begin{array}{l}\text { London (as with all of the } \\
\text { UK) }\end{array}$ & $100 \%$ & $0 \%$ & $0 \%$ \\
Paris (as with all of France) & $69 \%$ & & \\
Toronto (city) & $0 \%$ & $15 \%$ & $15 \%$ \\
\hline
\end{tabular}

Sources: For Boston and San Francisco: 2016 Public Elementary-Secondary Education Finance Data from the U.S. Census Bureau, available at https://www.census.gov/data/tables/2016/econ/school-finances/secondary-educationfinance.html; for Paris: Maryline Baumard, "École: les moyens attribués renforcent les inégalités," Le Monde (2012): December 4; and for London: Geraint Johnes, "How school funding works in England — and why it needs reform," The Independent (2016): July 5. Note: detailed tabulation of regional versus local contributions to education costs in the Paris region were not available, so we have split the data evenly between the two.

Fiscal competition through taxation and redistribution

Cities in North America and Europe alike rely heavily on revenues from property taxes, as we emphasize here (and detail in Appendix B). However, in each of the non-U.S. cities examined, redistribution from wealthy to poor municipalities serves as a mechanism to reduce the inequality-generating effects of fragmentation.

Localities in the United States are notoriously dependent on property taxes, and municipalities frequently orient policies toward attracting high-income households and businesses and increasing property values. ${ }^{70}$ Reliance on locally generated taxes also means that wealthy jurisdictions with high-value properties can tax those properties at a lower rate while poor jurisdictions are forced to charge their lower-income residents relatively higher tax rates. Both California and Massachusetts have passed state laws that impose limitations on increasing residential property taxes. In response to these limitations, many municipalities have sought revenue elsewhere, from sales and income taxes and from fees, possibilities that are more circumscribed in the other countries. In California, cities have turned to sales taxes and fees, and 
then fight among themselves to attract businesses (e.g., car dealerships) that generate high revenues through such taxes. ${ }^{71}$ Municipalities in other parts of the United States, such as the St. Louis suburbs, have turned to tickets, fines, and court fees to fund municipal budgets, costs that are disproportionately borne by lower-income and Black and Latinx residents. ${ }^{72}$

In the London, Paris, and Toronto regions, property taxes are also the primary revenue source for local governments, and municipalities generally control rates. ${ }^{73}$ In Paris and Toronto, local governments are largely self-funding, while more than 60 percent of London borough revenues originate from national-government transfers. In none of the other case-study regions is there a special local sales tax, as is common in the United States, nor is there an income tax executed locally. In the Paris region, a payroll tax provides most of the funding for regional transit services. All of the regions assess levies, in some cases user fees, such as for trash collection or water. In the London and Paris regions, negotiated development agreements or taxes on new development or commercial space fund subway-line construction. Île-de-France also raises money on car registrations and is funded by national energy taxes. ${ }^{74}$

As in the United States, the reliance on property-tax revenues produces inequities across local jurisdictions. This is particularly true in the London and Paris regions, where revenues from commercial property taxes are far higher in areas with plentiful office space (such as Westminster or the City of Paris) than in predominately residential areas (such as Harrow or Clichy-sous-Bois). As a result, property tax rates on housing in the latter areas are typically higher, and municipalities have less tax capacity to spend on local needs.

In each of the non-U.S. case-study regions, however, significant redistributive mechanisms mitigate the inequality-inducing effects of these differences. For example, education funds are largely equalized across municipalities through national or provincial funding 
formulas. Transport services are offered regionally, rather than being distributed among counties, as is partly true in the Bay Area. In France, there are several policies that redistribute resources, both vertically, as a significant portion of the national government budget is allocated through block grants with a focus on low-income areas, and horizontally, through required transfers between municipalities and counties based on their respective tax capacities. One key element of the structure of the Métropole du Grand Paris is a territorial fund that collects revenues from commercial property taxes and redistributes it to areas with low property tax revenues. ${ }^{75}$

Thus, despite a shared reliance on property taxes across all five regions, the existence of national-government funding for important local services such as schools, as well as mechanisms for redistribution, have an impact on how tax rates are distributed. In comparing the municipalities in the Boston, London, Paris, and Toronto regions in Table 3, we find a far greater spread in local property tax rates—-both residential and commercial—in the Boston region than in the cities in Canada or Europe. This is especially true for commercial rates, which are standardized across boroughs in London but differ dramatically among municipalities in the Boston area. 
Table 3: Distribution of tax rates for municipalities by region (2018)*

\begin{tabular}{|c|c|c|c|}
\hline & $\begin{array}{l}1^{\text {st }} \text { quartile rates as } \\
\text { percentage of median }\end{array}$ & $\begin{array}{l}3^{\text {rd }} \text { quartile rates as } \\
\text { percentage of median }\end{array}$ & Spread \\
\hline \multicolumn{4}{|l|}{ Boston region } \\
\hline Residential rates & $89.5 \%$ & $132.5 \%$ & $43 \%$ \\
\hline Commercial rates & $87.1 \%$ & $138.7 \%$ & $51.6 \%$ \\
\hline \multicolumn{4}{|l|}{$\begin{array}{l}\text { London region } \\
\text { (GLA by borough) }\end{array}$} \\
\hline Residential rates & $92.0 \%$ & $109.2 \%$ & $17.2 \%$ \\
\hline Commercial rates & $100 \%$ & $100 \%$ & $0 \%$ \\
\hline \multicolumn{4}{|l|}{ Paris region } \\
\hline $\begin{array}{l}\text { Housing plus building } \\
\text { rates }\end{array}$ & $85.2 \%$ & $115.2 \%$ & $30.1 \%$ \\
\hline \multicolumn{4}{|l|}{ Toronto region } \\
\hline Residential rates & $93.9 \%$ & $128.1 \%$ & $34.2 \%$ \\
\hline Commercial rates & $89.6 \%$ & $123.8 \%$ & $34.2 \%$ \\
\hline
\end{tabular}

Sources: Dan Seiffert, “Massachusetts property-tax rates in 2018, by town and city, ” Boston Business Journal, 22 January; London Councils, 2018-19 Council Tax Monitor; Insee tax data for France; individual municipality websites in the Toronto region. * No information was provided for the San Francisco region because of the existence of overlapping special units of government with their own property taxes and whose borders do not align with those of municipal governments.

The more dramatic differences in tax rates between municipalities around Boston produce a self-reinforcing cycle. Wealthier communities have more valuable commercial and residential property, so they can tax it at a lower rate and still produce the same revenue. This lower rate further contributes to such cities' desirability, increasing local land value and allowing lower tax rates over time, creating a virtuous cycle. By contrast, communities with lower property values are stuck in a vicious cycle. Without substantial state and federal transfers, they have to raise rates to supply basic services, thereby decreasing municipal desirability.

In sum, no major urban center is free of all patterns of spatial inequality; indeed, residential segregation and inequality seem to be a feature of modern urban life in rich democracies. Where the U.S. cities differ from their peers in other countries, however, is in the ease with which more affluent cities can formally separate themselves from less-affluent neighbors and hoard resources in ways that exacerbate unequal access to public goods and 
services. The resulting patterns of exclusion exhibit strong self-enforcing dynamics, but, as the next section demonstrates, they are neither inexorable nor irreversible. Recent developments in London, Paris, and Toronto suggest some of the ways the dynamics of municipal fragmentation can be combatted and even partly reversed.

\section{Opportunities for change: "Swinging the door" away from fragmentation- based opportunity hoarding}

Since 1815 , only 39 attempts at city-county consolidation among the 3,069 county governments in the United States have been successful. ${ }^{76}$ By contrast, since 2000 alone, 73 municipalities or school districts have succeeded in seceding, largely to hoard educational resources. ${ }^{77}$ If anything, this sort of jurisdictional proliferation sets in motion self-enforcing dynamics. Trounstine, notably, traces the evolution of metropolitan settlement in the United States over the past century, as residential segregation proceeded first block-by-block, then neighborhood-by-neighborhood, then city-by-city. ${ }^{78}$

First-dimension fragmentation via jurisdictional proliferation has often proceeded through incremental and "hidden" processes — for example, as populations shift while the boundaries of local government are held in place. Consistent with theories of institutional change through drift, wealthy white homeowners have been able to effect significant de facto transitions simply by blocking efforts to update municipal boundaries - resisting efforts to subsume the new communities they form into larger metropolitan entities. Second-dimension fragmentation via resource hoarding, likewise, does not typically involve open political contestation over distribution, but instead follows "naturally" from the normal operation of markets. This is especially true for real-estate markets, as otherwise progressive property taxes turn regressive 
when their rates are set by different jurisdictions that collect revenues independently and then use them to fund exclusively local services.

These dynamics raise the question of whether metropolitan fragmentation and its more deleterious consequences are inevitable and irreversible-whether, in effect, the door only swings one way. This section considers instances in which this has not been the case, exploring reforms intended to mitigate or even reverse the effects of metropolitan fragmentation. We show that the few attempts to reverse jurisdictional proliferation in the United States have been layered on top of existing institutions and have had little impact on inequality. We then examine more recent policies outside the United States to limit or reduce opportunities for resource hoarding by overriding or replacing existing rules, showing that these have been more effective. We summarize these changes in Appendix C.

\section{Changes in first-dimension fragmentation: Reducing jurisdictional proliferation}

As discussed, some features of local governance in London, Paris, and Toronto make processes of first-dimension drift toward jurisdictional proliferation substantially weaker. The incorporation of all land (England and France) renders strategies of defensive incorporation or secession irrelevant, while the need to secure agreement from higher levels of government for incorporation (Ontario) makes it more difficult. Moreover, governments elsewhere have either actively imposed municipal mergers (London and Toronto) or encouraged them (France).

In the United States, efforts to counteract the impact of jurisdictional proliferation arguably reached their apex in the 1960s and 1970s. Since 1962, the federal government has used federal transportation funds as an incentive to encourage inter-municipal cooperation through councils of government and metropolitan planning organizations. These agencies are supposed to 
identify appropriate transportation investments by prioritizing regional needs. Yet these incentives have not, for the most part, led to greater regional coordination. ${ }^{79}$ Indeed, even the most ambitious such efforts have had limited success. For example, in 1994, the Minnesota legislature expanded the Metropolitan Council, an appointed regional government serving the Twin Cities region, and authorized it to coordinate transportation policies for the entire area. In a similar move, in 1978, Oregon voters by referendum created the directly elected Metro government to conduct long-term planning and provide solid waste and parks services to the Portland region. In both cases, however, these institutions were layered on top of existing local governments, which retained most of their land-use powers, impeding the implementation of plans developed by these higher-order governance institutions. ${ }^{80}$

Initiatives in other metropolitan areas have sought to promote governmental consolidation through city-county mergers. One example was the consolidation of Marion County, Indianapolis, and 11 other localities into an overarching "Unigov," which in 1970 displaced certain existing locally run programs (though many, such as schools, continue to operate under pre-merger boundaries) ${ }^{81}$ Even these more ambitious efforts have had little impact, in part because population shifts and the creation of new municipalities outside of the boundaries of their respective metropolitan governments have continued apace. For instance, Marion County now includes just 47 percent of the Indianapolis metropolitan area's population, down from 55 when Unigov was created.

A core problem in the United States is that encompassing metropolitan planning organizations such as these lack formal power over localities. Thus, despite often-lofty goals established in their regional plans (such as reducing inequality or stemming sprawl), these initiatives must be embraced and actively pursued by cities whose leaders are often not willing to 
spend the political capital necessary to implement the steps (such as eliminating exclusionary zoning or reducing roads construction) that would be needed to realize their goals. Efforts at consolidation face strong political headwinds since they typically provoke fierce opposition among powerful local actors. In the face of such resistance, proponents of regional equity often turn instead to voluntary coalition building and cooperative strategies to address regional differences. ${ }^{82}$ Yet these more modest approaches, at least thus far, have had even less of an effect in reversing the direction of fragmentation; intra-regional inequality continues to increase and further jurisdictional proliferation rather than consolidation is the norm in many U.S. regions.

Governments in other countries have sought to combat jurisdictional proliferation though two countervailing, but complementary measures: the devolution of power down from national governments and the concentration of local powers up into new, metropolitan institutions. In some cases, the key changes were undertaken by left governments whose express objectives were to empower local governments while also promoting metropolitan-level cohesiveness. Thus, for London, the 1999 law creating the GLA delegated control over transport and policing down from the national government to the new metropolitan authority. At the same time, it transferred significant planning powers up from the boroughs to the GLA, adding new powers to existing mechanisms. For Paris, as we saw, devolution of authority down from the national government in the 1980s was followed by policies transferring power over planning up from local governments to more encompassing governance structures such as the Métropole du Grand Paris. And although the changes in Toronto were inspired by very different motives, the 1998 amalgamation similarly involved a dual transfer of competencies—shifting taxation powers down from the provincial level to the City of Toronto, while also transferring land-use and other powers up from previously independent municipalities. 
The political forces that supported these changes have thus varied widely, but these reforms were invariably achieved through open (often conflictual) processes of either institutional layering or outright policy displacement. Thus, London's long history of metropolitan coordination has unfolded largely through policies of institutional layering, in which smaller entities were successively enveloped in more overarching governance structures. ${ }^{83}$ In France, institutional layering related to first-dimensional fragmentation similarly steadily increased the power of regional governments, among other things by granting them jurisdiction over transportation and the regional plan. As in the case of London, the creation of new metropolitan governments for French cities reflected a broad, multiparty concern about the management of services in urban areas, in this case especially since the 2005 riots. Actors on both the left and right, and from both municipalities and counties, have resisted a transition to a fully unified local-level government, unwilling to relinquish their authority over important questions such as land use. But the development of inter-communal service providers reduced the tendency of municipalities to act independently, and local actors have also been more willing to address the second dimension of fragmentation, to which we now turn. ${ }^{84}$

\section{Changes in second-dimension fragmentation: Reducing resource hoarding}

Policies such as merging municipal governments or facilitating annexation are designed to limit first-dimension fragmentation. But others, such as requiring zoning to meet regional or national goals, can be applied to combat second-dimension fragmentation via resource hoarding regardless of a region's degree of jurisdictional proliferation. Existing laws about how local governments exercise power over affordable housing, land use, and taxes in the United Statesissues that lie at the heart of the second dimension of fragmentation-encourage and actively 
enable resource hoarding. Most U.S. municipalities establish zoning rules that tightly restrict land uses, often banning all but single-family homes from residential neighborhoods. Moreover, our U.S. case-study regions, like others in the nation, rely on locally generated property and sales taxes and fees to fund many crucial services - even as support declines from federal programs such as the Community Development Block Grants that were designed to spread local resources somewhat more evenly. This reliance on local revenues and shrinking federal support produces inequitable outcomes because of wide variation in the tax bases of adjacent jurisdictions.

Reforms undertaken abroad point to some measures that mitigate these trends. In terms of affordable housing, French law allows the national government to override local zoning, develop subsidized units, and fine cities that do not meet certain goals. Socialist victories in 1997 and 2012 provided opportunities for the national government to pass laws enforcing a minimum level of social housing in municipalities throughout the country. In a similar move, Labour Mayor of London Sadiq Khan in 2016 implemented a requirement that 35 percent of housing units in major new housing projects accommodate low-income families.

Moreover, in both England and France, low-income families are entitled to vouchers that can be used in privately owned units. ${ }^{85}$ Housing vouchers mean that lower-income households pay less of their income towards housing than in the United States. And because it is more difficult for municipalities to exclude them even from areas where no publicly subsidized lowincome housing is built, lower-income families elsewhere also enjoy more geographic mobility. Policies in Paris and London are far stronger than those in Boston or San Francisco, where housing vouchers are not an entitlement. Federal housing vouchers in the United States are limited, reaching only about one-quarter of income-eligible households, and most jurisdictions in the United States allow landlords to discriminate against households seeking to use them. 
In the United States, metropolitan planning is also weak compared to its counterparts abroad — and typically unenforceable as well. In London, Paris, and Toronto, regional plans regarding matters such as housing-growth objectives must be reflected in local land-use policies. In these cases, the distribution of jurisdictional competencies over land use allows localities to retain some influence over their growth, but denies them the ability to use this influence to hoard resources. Higher-level rules that encourage—in some cases, require—-localities to meet the housing needs of a diverse population make it difficult for communities to resist uses as important as multi-family housing. All of the regions outside the United States back these policies up by providing administrative appeals processes (London and Toronto) or by allowing higher-level administrative actors to reject local plans when they do not conform with broader goals (London and Paris).

Finally, several of the regions outside the United States have developed responses to the fiscal patterns that fuel local hoarding. In Toronto, the province equalizes tax rates across jurisdictions to fund schools, and in Paris, some revenues are redistributed at the metropolitan level. In all three non-U.S. regions, many services are provided directly by the national or metropolitan governments, making the particular municipality where an individual lives less relevant to the quality of services she enjoys. All these policies—on affordable housing, land use, taxes, and service provision — are relatively independent of the degree of jurisdictional fragmentation.

Figure 2 summarizes stylistically where the metropolitan regions that we have examined fall in terms of the two dimensions of fragmentation, indicating the direction of several key recent changes. The chart shows how the non-U.S. cities have addressed both dimensions of fragmentation. Toronto's amalgamation consolidated previously separate local governments, 
displacing existing municipalities and making the region less fragmented from a first-dimension perspective. The creation of equalized school funds in Ontario reduced second-dimension opportunities for hoarding even outside of the Toronto city limits. Similar changes occurred in London as a result of the creation of the GLA, layered onto existing local governments as an overarching governing body, and by empowering the Mayor of London to exercise oversight over land-use. As indicated in the figure, Paris has not experienced significant change on the first dimension (jurisdictional proliferation), but national affordable housing requirements have reduced second-dimension fragmentation by discouraging efforts to exclude low-income families. Finally, Figure 2 also captures how forces of drift have made metropolitan areas in the United States more fragmented in both dimensions over time. 
Figure 2

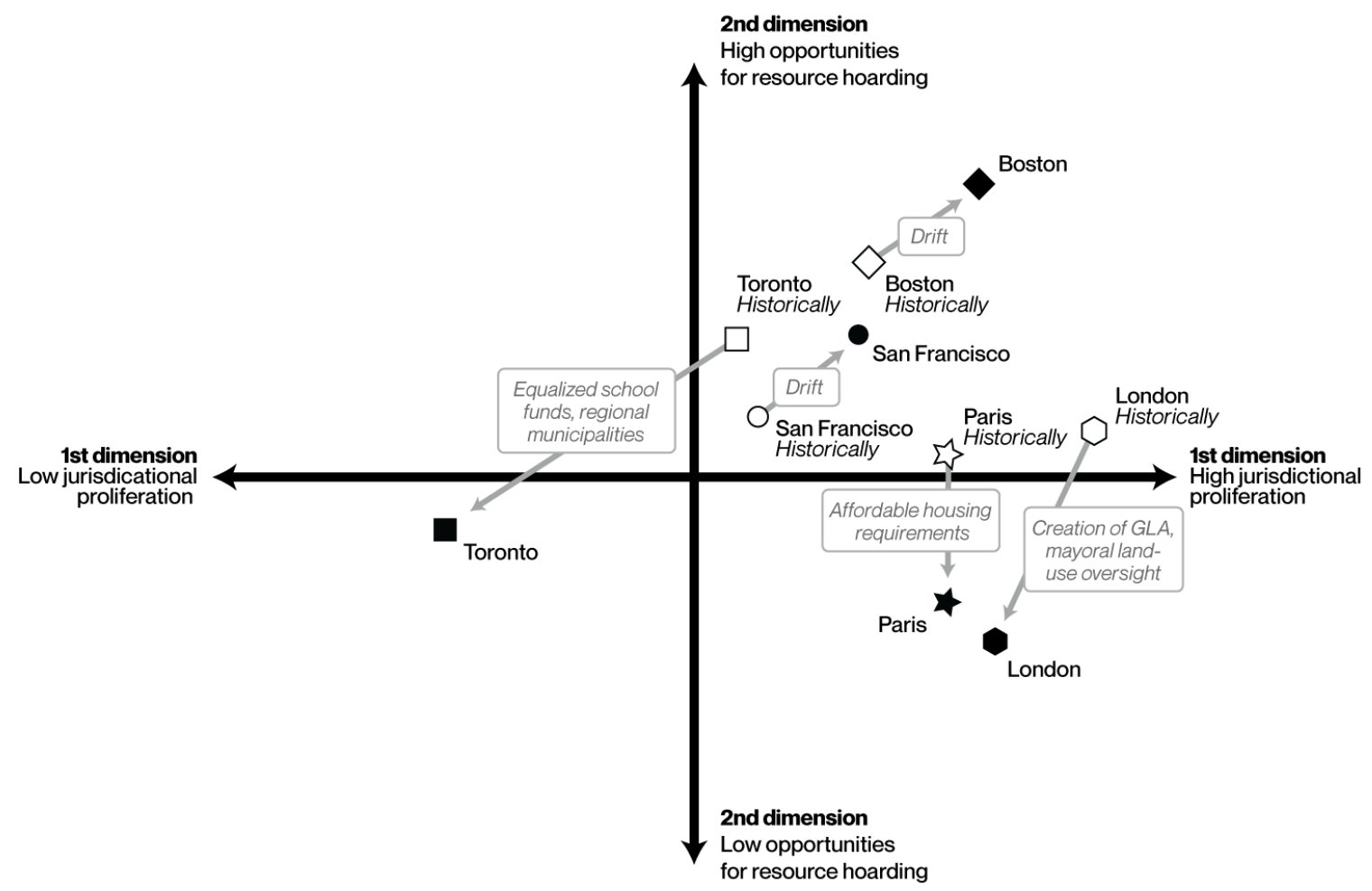

Caption: Stylized position of case-study regions on dual dimensions of fragmentation, with key changes highlighted. Source: The authors.

\section{Conclusion}

The United States stands out among the rich democracies in the way in which the institutional structure of local governance facilitates (indeed, incentivizes) jurisdictional proliferation and actively supports resource hoarding, typically by affluent white homeowners. Situating the United States in a comparative perspective provides insights into some of the most distinctive structural features of the American political economy that are closely associated with soaring wealth inequality, declining social mobility, and persistent racial and ethnic economic divides. Cross-national comparisons make clear that some of the inequalities associated with metropolitan growth in the United States are neither inevitable nor inexorable. Over the past 
three decades, each of the three case regions outside the United States has undertaken steps to reduce jurisdictional proliferation and/or oppose resource hoarding, with political officials at the national and provincial levels undertaking institutional reforms that displace existing policies rather than surrender control over outcomes to processes of drift and conversion. These reforms have made it less feasible or, often, simply less advantageous, for groups to deploy policies of exclusion, municipal parochialism, and fiscal competition in order to hoard resources at the expense of neighboring communities. Indeed, strict limits on resource hoarding may itself help explain why jurisdictional proliferation has not increased in these other cases.

Cross-national comparison can also serve to identify more (and less) promising avenues for reform even within the United States. At the state level, progressives who hope to reduce resource hoarding, at least in terms of planning, can look abroad for examples of policies that address both dimensions of fragmentation. The most obvious mechanism to reduce jurisdictional proliferation would be to encourage annexation, though in itself this is unlikely to be a durable solution in light of how quickly metropolitan regions are expanding. In the U.S. context, communities on the edge of metropolitan regions have proven highly resourceful in identifying ways to defensively incorporate, hoard their resources, and maintain high-income and white racial isolation. Another policy option is to develop more powerful metropolitan institutions or merge city and county governments as in London and Toronto. Here, too, however, experience over the last few decades suggests that this approach is likely to have limited success due to resistance from local leaders.

Alternatively, and more promisingly, states can take a page from the playbook of the other cases we have examined here and develop strategies to reduce incentives to hoard resources, tackling the second dimension of fragmentation. Recent legislation passed in 
California may point a way forward from this perspective. The state now requires municipalities to allow accessory dwelling units, expanding access to low-scale, lower-cost housing in neighborhoods that now feature only single-family homes. State law allows developers of affordable housing projects to build larger projects throughout the state, and the governor suggested he might withhold state funding for transportation projects in communities that were not meeting housing production targets. ${ }^{86}$ Similarly, in 2019, the Oregon legislature passed a law requiring cities to allow duplexes in neighborhoods currently zoned for single-family homes; in the Portland region, even higher-density building will be made as-of-right, meaning faster development approval and integration of different types of housing units in such communities. ${ }^{87}$ In each case, local rights to make most decisions about planning remain in effect, but the link between these decisions and the ability to exclude are somewhat attenuated. Deeper reforms would of course be necessary to limit local governments' control of revenues from their tax bases, and to impose more uniformity in local education provision and other public services.

Effective strategies may require approaches on both dimensions of fragmentation, though the kinds of measures needed will provoke conflict. Our optimism should therefore be tempered by the fact that previous efforts for more equitable urbanism in the United States, such as through revenue sharing and national planning, have failed repeatedly, generally in the face of local opposition and resistance from homeowner and real estate interests. ${ }^{88}$ The California Senate's recent failure to pass SB 50, which would have allowed apartments in many now-exclusive communities, illustrates the continued obstacles even for progressive state governments to make progress on limiting resource hoarding. Moreover, the increasing use of preemptive legislation by conservative state legislatures limits city efforts to act progressively. ${ }^{89}$ Municipalities in the United States are caught in a trap between openness to action and the constant threat of state 
intervention; they may have some freedom to make decisions about local policy, but cities with fewer resources are less likely to be able to meet the needs of their inhabitants.

Nonetheless, the recent statutory changes enacted for London, Paris, and Toronto suggest that it is possible to swing the door at least partly in the opposite direction. Policy levers can begin to reverse the seemingly inevitable advance of jurisdictional proliferation and stem the resource hoarding associated with widening racial and economic inequality. Although uneven development is a fact of modern capitalist geography, it does not have to be calcified into political geography through legally sanctioned opportunity hoarding. Rather, the creation of new institutional structures that attempt to counteract it is possible. The experiences of the non-U.S. cities considered here provide an initial template for cities to begin to work proactively against hoarding, even as cities in the United States drift further into it. 


\section{Acknowledgements}

We thank Alex Hertel-Fernandez, Jessica Trounstine, and Margaret Weir, attendees of the Political Geography \& Inequality Workshop held at Brown University in December 20I8, and the editors at Politics \& Society for their thoughtful feedback.

\section{Declaration of Conflicting Interests}

The authors declared no potential conflicts of interests with respect to the research, authorship, and/or publication of this article.

\section{Funding}

The authors received no special funding for the pursuit of this research.

\section{Notes}

\footnotetext{
${ }^{1}$ U.S. Census Bureau, 2017 Census of Governments: Organization Component Estimates (2019).

${ }^{2}$ Myron Orfield, American Metropolitics: The New Suburban Reality (Washington: Brookings Institution Press, 2002); and Jon Teaford, City and Suburb: The Political Fragmentation of Metropolitan America, I850-1970 (Baltimore: Johns Hopkins University Press, 1979). See also Kenneth T. Jackson, The Crabgrass Frontier (Oxford: Oxford University Press, 1985); Clyde Mitchell-Weaver, David Miller, and Ronald Deal, Jr., "Multilevel Governance and Metropolitan Regionalism in the USA," Urban Studies 37, no. 5-6 (2000): 85I-876.

${ }^{3}$ Peter Hegarty, "Proposal to install license plate readers in Alameda put on hold," East Bay Times (February 7 , 20I8).

${ }^{4}$ This quote is from Tom McCullough, a member of the Signal Mountain committee, which pushed for the schools split. See Kendi A. Rainwater, "Shelby County visit provides insight for possible Signal Mountain schools split," Times Free Press (July 6, 2017).
} 
${ }^{5}$ See for example, Vivien Schmidt, Democratizing France: The Political and Administrative History of Decentralization (Cambridge: Cambridge University Press, 1990); Jeremy Ferwerda, The Politics of Proximity: Local Redistribution in Developed Democracies (MIT PhD Thesis, 2017); Jose Alonso, Judith Clifton and Daniel Diaz-Fuentes, “Did New Public Management Matter?” Public Management Review I7, no. 5 (2015): 643-66o; Maurizio Ferrera, The Boundaries of Welfare (Oxford: Oxford University Press, 2005).

${ }^{6}$ This quote is from Francis Chouat, the former mayor of Évry, a city south of Paris, which merged with its neighbor Courcouronnes to create the new city Évry-Courcouronnes. Pascale Tessier, "Communes nouvelles : Evry et Courcouronnes veulent se marier," La Gazette (January 22, 2018).

${ }^{7}$ For an exception to this, and a study that is complementary to ours, with a focus on housing, see Patrick Le Galès and Paul Pierson, “'Superstar Cities' \& the Generation of Durable Inequality,” Daedalus I48, no. 3 (2019): 46-72. ${ }^{8} \mathrm{We}$ focus on the formal governmental institutions and practices associated with metropolitan fragmentation crossnationally. An exploration of the origins of such fragmentation is beyond the scope of this analysis. Clearly in the U.S. this is a story that is bound up in the history of racial domination. For an account of the ways in which federal policies promoted housing segregation, see Richard Rothstein, The Color of Law (New York: Norton, 20I7).

${ }^{9}$ Our analysis builds on work by Sellers et al., who detail different approaches to metropolitan governance, by clarifying what is meant fragmentation. See Jeffrey Sellers, Marta Arretche, Daniel Kübler, and Eran Razin, Inequality and Governance in the Metropolis (London: Palgrave Macmillan, 2017).

${ }^{10}$ On drift and conversion, see Jacob Hacker, Paul Pierson and Kathleen Thelen, "Change without Reform, Reform without Change: The Hidden Faces of Institutional and Policy Transformation,” in James Mahoney and Kathleen Thelen, eds., Advances in Comparative Historical Analysis (New York: Cambridge University Press, 2015).

${ }^{11}$ Archon Fung, Empowered Participation: Reinventing Urban Democracy (Princeton: Princeton University Press, 2006); Jeffrey Berry, Kent Portney, Ken Thomson, The Rebirth of Urban Democracy (Washington DC: Brookings Institution Press, 1993).

${ }^{12}$ Charles Tiebout, “A Pure Theory of Local Expenditures," Journal of Political Economy 64 (I956): 4I6-424.

${ }^{13}$ Barry R. Weingast, “The Economic Role of Political Institutions: Market-Preserving Federalism and Economy Development," Journal of Law, Economics, and Organization II (I995): I-3I.

${ }^{14}$ Paul Peterson, City Limits (Chicago: University of Chicago Press, I98I). 
${ }^{15}$ Reto Steiner, Claire Kaiser, Christopher Tapscott, and Carmen Navarro, "Is local always better? Strengths and limitations of local government for service delivery.” International Journal of Public Sector Management 3I, no. 4 (20I8): 394-409; William H. Riker, Federalism: Origin, Operation, and Significance (Boston: Little Brown, I964).

${ }^{16}$ Ira Katznelson, City trenches: Urban politics and the patterning of class in the United States (Chicago: University of Chicago Press, I982); Clarissa Hayward, How Americans Make Race (Cambridge University Press, 20I3); Margaret Weir, Harold Wolman, and Todd Swanstrom, "The Calculus of Coalitions: Cities, Suburbs, and the Metropolitan Agenda," Urban Affairs Review 40, no. 5 (2005): 730-760; Jessica Trounstine, Segregation by Design (Cambridge University Press, 20I8); Katherine Einstein, David Glick, and Maxwell Palmer, Neighborhood Defenders: Participatory Politics and America's Housing Crisis (New York: Cambridge University Press, 20I9).

${ }^{17}$ See Peter A. Hall and David Soskice, Varieties of Capitalism: The Institutional Foundations of Comparative Advantage (Oxford: Oxford University Press, 200I).

${ }^{18}$ See Edward J. Malecki, “Cities and Regions Competing in the Global Economy: Knowledge and Local Development Policies," Environment and Planning C 25, no. 5 (2007): 638-654; and Willem van Winden, Leo van den Berg, and Peter Pol, "European Cities in the Knowledge Economy: Towards a Typology," Urban Studies 44, no. $3(2007): 525-549$.

${ }^{19}$ For statistics on clusters of venture-capital investment around the world, see Richard Florida, "The Global Cities Where Tech Venture Capital Is Concentrated," The Atlantic (January 26, 20I6). Note that that the city of San Jose is part of the same metropolitan area as the city of San Francisco.

${ }^{20}$ Christopher R. Berry, Imperfect Union: Representation and Taxation in Multilevel Governments (Cambridge: Cambridge University Press, 2009).

${ }^{21}$ See Joe Soss and Vesla Weaver, "Police are our government: Politics, political science, and the policing of raceclass subjugated communities," Annual Review of Political Science 20 (2017): 565-59I; Desmond King and Rogers Smith, Still a House Divided (Princeton: Princeton University Press, 20II); Jennifer Hochschild, Facing Up to the American Dream (Princeton: Princeton University Press, I995); Claudine Gay, "Legislating Without Constraints: The Effect of Minority Districting on Legislators' Responsiveness to Constituency Preferences," The Journal of Politics 69, no. 2 (2007): 456; Danielle Allen, Talking to Strangers (Chicago: University of Chicago Press, 2004). ${ }^{22}$ Robert B. Reich, "The Secession of the Successful," New York Times Magazine, January 20, I99I; on the concept of opportunity hoarding see also Charles Tilly, Durable Inequality (Berkeley: University of California Press, I998). 
${ }^{23}$ Sheryll D. Cashin, "Localism, Self-Interest, and the Tyranny of the Favored Quarter: Addressing the Barriers to New Regionalism," Georgetown Law Journal 88 (2000): 1985.

${ }^{24}$ See Michelle Wilde Anderson, “The New Minimal Cities," Yale Law Journal I23, no. 5 (20I4): III8-I625; Andre Sorensen, "Taking path dependence seriously: an historical institutionalist research agenda in planning history," Planning Perspectives 30, no. I (2015): I7-38; Paul Pierson, Politics in Time: History, Institutions, and Social Analysis (Princeton: Princeton University Press, 2004).

${ }^{25}$ Clayton Nall, The Road to Inequality: How the Federal Highway Program Polarized America and Undermined Cities (New York: Cambridge University Press, 2018).

${ }^{26}$ H.V. Savitch and Sarin Adhikari, "Fragmented Regionalism: Why Metropolitan America Continues to Splinter," Urban Affairs Review 53, no. 2 (2017): 38I-402.

${ }^{27}$ Because the positioning of the cases relies heavily on deep qualitative familiarity with each of the cases, we think it is unwise to impose a rigid index. However, to ensure correspondence between our findings and the quantitative measures we present later in the paper, we assigned weights to key aspects of each dimension to determine the relative position of each of the cases. Thus, the horizontal dimension is captured, loosely, on the normalized Herfindahl index of population that we discuss (the order of cities on the horizontal dimension is the same as their order based on the Herfindahl index). Note that London's position is based on treating boroughs as the essential unit of local government due to their control over land-use decisions and policies such as council housing and some school-related issues. If we instead used the more overarching Greater London Authority (GLA) as a unitary municipality, the London region would have the lowest levels of jurisdictional proliferation among the regions studied; but this choice would efface the real importance of the boroughs as a level of government. See Alan Mace and Alan Sitkin, "Planning at the Interface of Localism and Mayoral Priorities: London's Ungovernable Boroughs," Planning Theory \& Practice, online pre-print (2019). For the second dimension, we constructed a composite measure (again normalized) of three aspects of opportunity hoarding that this dimension is designed to capture (exclusion through barriers to entry, municipal parochialism, and fiscal competition, elaborated and presented in Tables I through 3). We hasten to add that these figures are non-interpretable other than as a comparison to one another, and we deploy them only to situate the cases in this two-dimensional space relative to one another and as a check on our own qualitative understanding of the cases. Other cases could also be situated in this space relative to each other and to the cases around which we have organized our study. 
${ }^{28}$ U.S. Census I960 and 2010.

${ }^{29}$ Savitch and Adhikari, "Fragmented Regionalism;” and Frug, "Beyond Regional Government."

${ }^{30}$ Briffault, "Our Localism;” and Dale Krane, Platon N. Rigos, and Melvin Hill, Home rule in America: A fifty-state handbook (Washington, D.C.: CQ Press, 200I).

${ }^{31}$ In some states, counties or even state legislatures do have to approve incorporations; other states (Arkansas, California, Kentucky, Louisiana, Michigan, New Mexico, North Dakota, Utah, Vermont, and Wisconsin) call for approval through special commissions, state agencies, or administrative judges. See Krane et al., Home rule in America.

32 Jamie L. Palmer and Greg Lindsey, “Classifying State Approaches to Annexation,” State \& Local Government Law Review 33, no. I (200I): 60-73.

33 Jackson, Crabgrass Frontier.

${ }^{34}$ There are 7.9 million people in the San Jose-San Francisco-Oakland, California Combined Statistical Area. Office of Management and Budget, OMB Bulletin No. I8-04.

35 There are 4.8 million people in the Boston-Cambridge-Newton, Massachusetts-New Hampshire Metropolitan Statistical Area. Office of Management and Budget, OMB Bulletin No. I8-04: Revised Delineations of Metropolitan Statistical Areas (20I8).

${ }^{36}$ See Massachusetts Constitution, Article 89; California Constitution, Article XI. In the majority of states, any local government authority must be explicitly granted to the state by the state legislature, pursuant to the rule of statutory construction known as Dillon's Rule (for further resources on home rule powers and Dillon's Rule, see e.g., Richard Briffault, “Home Rule, Majority Rule, and Dillon's Rule,” Chicago-Kent Law Review, 67 (I99I): IoII; David J. Barron, “Reclaiming Home Rule,” Harvard Law Review (2003): 2255-2386.

${ }^{37}$ Legal scholars David Barron and Gerald Frug (2005) have argued that these limitations on local authority encourage "an insular and defensive mindset that makes regionalism an unattractive risk" and that the United States is characterized by "defensive localism - the defense of local power in order to preserve the status quo." See David J. Barron and Gerald E. Frug, "Defensive Localism: A View of the Field From the Field," Journal of Law \& Policy 2I (2005): 26I.

38 "Ken Reclaims the Capital," The Independent (May 6, 2000). 
${ }^{39}$ See Mace and Sitkin (2019); and Brian Smith, "Accountability in metropolitan government: the case of Greater London," Geographica 2 (2002): 5I-63.

${ }^{40}$ See Michaela Benson, Gary Bridge, and Deborah Wilson, "School Choice in London and Paris-A Comparison of Middle-class Strategies," Social Policy and Administration 49, no. I (2015): 24-43; Andrew Eyles and Stephen Machin, "Academy schools and the transformation of the English education system," Oxford University Press Blog (2016): December I4; and Mayor of London, New London Plan (2018).

${ }^{41}$ There are portions of the London metropolitan area that are outside of the GLA (and its component boroughs), but in this paper, we limit our analysis to the GLA area. See U.K. Government, "Local government structure and elections" (20I6; online at https://www.gov.uk/guidance/local-government-structure-and-elections); Local Government Association, "Local government structure overview" (2010; online at https://www.local.gov.uk/sites/default/files/documents/local-government-structur-634.pdf); and Jonn Elledge, “American cities are much more powerful than British ones—and that's not always a good thing," CityMetric (April 22, 2016).

${ }^{42}$ Intercommunal relationships act as a government level in between municipalities and counties, but do not have directly elected offices. See Maryline Baumard, "École: les moyen attribués renforcent les inégalités," Le Monde (December 4, 2012); French Government, “Créer une commune nouvelle," Collectivités Locales (2016; online at https://www.collectivites-locales.gouv.fr/creer-commune-nouvelle-o); and French Ministère de l’Éducation Nationale, "Les régions académiques, académies et services départementaux de l'Éducation nationale" (20I7; online at http://www.education.gouv.fr/cid3/les-regions-academiques-academies-et-services-departementaux-de-1education-nationale.html).

${ }^{43}$ These paragraphs draw on Gilles Pinson and Patrick Le Galès, "State restructuring and decentralization dynamics in France: politics is the driving force," RTN Urbeurope (working paper, 2005; online at http://blogs.sciencespo.fr/recherche-villes/files/20Io/oI/cahier_ville_0507.pdf).

${ }^{44}$ Note that as of 2008, 85 percent of legislators in the French National Assembly and Senators held other elected positions. However, beginning in 2017, legislators were forbidden from also holding a role as mayor, adjunct mayor, or similar local executive role; that said, legislators can continue to sit on city, county, or regional councils. Ibid; see also Gilles Pinson, "The governance of French towns. From the centre-periphery scheme to urban regimes," Análise 
Social 45, no. 197 (2010): 717-737; and Elaine Sciolino, "French Cabinet Position Not Enough? Then Try Mayor," The New York Times (January I3, 2008).

${ }^{45}$ Pinson and Le Galès, 2005: 23.

${ }^{46}$ Ibid: I8.

${ }^{47}$ New communes can be created either (a) if all affected local councils affected by a merger agree; or (b) if twothirds of affected local councils in an existing intercommunal relationship (known as an EPCI), representing at least two-thirds of population, agree. New communes must remain within one département. The number of independent communes eliminated in 2015 and 2016 alone was higher than the total count of such eliminations between I97I and 20I0. See Vincent Aubelle, "Panorama des communes nouvelles," Association des Maires de France et des Présidents d'Intercommunalité, (2017): March; Hellmut Wollmann, “Comparing Two Logics of Interlocal Cooperation: The Cases of France and Germany," Urban Affairs Review 46, no. 2 (2010): 263-292; and Insee, “Communes nouvelles,” (January I5, 2019; online at https://www.insee.fr/fr/information/2549968).

${ }^{48}$ Our account relies heavily on Roger Keil, "Governance Restructuring in Los Angeles and Toronto: Amalgamation or Secession?" International Journal of Urban and Regional Research 24, no. 4 (2000): 758-78I; this quote is from p. 765 .

${ }^{49} \mathrm{Ibid}, 768$.

${ }^{50} \mathrm{Ibid}, 758$.

${ }^{51}$ See Ontario Ministry of Municipal Affairs and Ministry of Housing, "Municipal Restructuring" (February 20I8; online at http://www.mah.gov.on.ca/Page247.aspx); and Ontario Ministry of Municipal Affairs and Housing, "Restructured Municipalities: Ontario Map \#6 (2006; online at http://www.mah.gov.on.ca/Assetı6II.aspx).

${ }^{52}$ Briffault, "Our Localism;" William A. Fischel, The Homevoter Hypothesis: How Home Values Influence Local Government Taxation, School Finance, and Land-Use Policies (Cambridge: Harvard University Press, 200I); and Frug, City Making.

${ }^{53}$ Where such requirements exist, they often prove unenforceable.

${ }^{54}$ These figures are calculated based on the latest San Francisco zoning data. Other sources put the figure somewhat higher. A 2018 report suggests that between $53-54 \%$ is single-family only (online at https://www.livablecity.org/rethinking-rh/). It is worth noting that accessory dwelling units are, as of 20I9, allowed on all housing-zoned lots throughout California; thus the state has, in a way, eliminated single-family zoning. There 
are important efforts related to this worth investigating. A recent proposal by California State Senator Scott Weiner, for example, would require upzoning around transit throughout the state. For a comparative analysis of zoning policies, see Sonia A. Hirt, Zoned in the USA: The Origins and Implications of American Land-use Regulation (Ithaca: Cornell University Press, 20I4).

${ }^{55}$ Massachusetts count based on analysis of municipal-level figures produced by the state Department of Housing and Community Development as of September 2017 (online at https://www.mass.gov/files/documents/20I7/Io/Io/shiinventory_o.pdf).

${ }^{56}$ California Government Code $\S 65583$ (a) requires "An analysis of potential and actual governmental constraints upon the maintenance, improvement, or development of housing for all income levels, ... including land use controls, building codes and their enforcement, site improvements, fees and other exactions required of developers, and local processing and permit procedures...” There are some signs of change, as the state's new Governor, Gavin Newsom, is more aggressively pursuing communities that are not in compliance with the state's housing-supply law (“Why California's Governor is Suing Huntington Beach," The Economist, March 28, 2019). See also Paavo Monkkonen, Michael Manville, and Spike Friedman, “A Flawed Law: Reforming California’s Housing Element,” UCLA Lewis Center for Regional Policy Studies (2019; online at https://www.lewis.ucla.edu/2019/05/Io/rhnaflawed-law/).

${ }^{57}$ Organization for Economic Cooperation and Development, "The Governance of Land Use: United Kingdom” (20I7; online at thttps://www.oecd.org/regional/regional-policy/land-use-United-Kingdom.pdf); U.K. Department for Communities and Local Government, "Plain English guide to the Planning System" (January 20I5; online at https://assets.publishing.service.gov.uk/government/uploads/system/uploads/attachment_data/file/391694/Plain_Engl ish_guide_to_the_planning_system.pdf); and U.K. Department for Communities and Local Government, National Planning Policy Framework (2012): March.

${ }^{58}$ See City of London, Local Plan (January 20I5; online at https://www.cityoflondon.gov.uk/services/environmentand-planning/planning/planning-policy/local-plan/Documents/local-plan-20I5.pdf); Mayor of London, "What powers does the Mayor have for planning applications?” (2018; online at https://www.london.gov.uk/what-wedo/planning/planning-applications-and-decisions/what-powers-does-mayor-have-planning).

${ }^{59}$ Local plans do not incorporate zoning, but borough councils use plans to make choices about new projects. 
${ }^{60}$ The 2000 SRU law required $20 \%$ social housing per commune; this was expanded to $25 \%$ by 2025 under laws in 2013 and 2014, which also reinforced fines against noncompliant communities. See Direction régionale et interdépartementale de l'Équipement et de l'Aménagement d'Île-de-France, L'action des aménageurs publics pour la production de logements en Île-de-France (2017); and French Ministère de la Cohésion des Territoires, “Logement Social: L’Article 55 de la Loi SRU” (2018; online at http ://www.cohesionterritoires.gouv.fr/transparence-logement-social).

${ }^{61}$ Enforcement is undertaken by the national government representative, the prefect. The Urban Solidarity and Renewal law is referred to as the SRU in France; local plans are PLUs; intercommunal institutions are EPCI; and the Île-de-France regional plan is called SDRIF. See Yonah Freemark, "Doubling housing production in the Paris region: A multi-policy, multi-jurisdictional paradigm," International Journal of Housing Policy, online pre-print (2019); Direction Régionale et Interdépartementale de l’Équipement et de l'Aménagement d'Île-de-France, “Les plan local d'urbanisme (PLU) et plan local d'urbanisme intercommunal (PLUi)" (20I7; online at http://www.driea.ile-de-france.developpement-durable.gouv.fr/les-plan-local-d-urbanisme-plu-et-plan-local-da5I99.html); Véronique Dorel, "Le Récolement Genéral des PLU des I3I Communes de la Métropole," Atelier Parisien d'Urbanisme (20I8); French government, "Répartition des compétences," Collectivités Locales (20I5; online at https://www.collectivites-

locales.gouv.fr/files/files/Annexe_I_Tableau_des_competences_Communes__Departements__Regions_I40I20I6. pdf); French Ministère de la Cohésion des Territoires, "Caducité des Plans d'occupation des sols (Loi Alur)" (20r6; online at http://www.cohesion-territoires.gouv.fr/caducite-des-plans-d-occupation-des-sols-loi-alur); and Métropole du Grand Paris, "La Métropole et ses compétences” (20I8; online at http ://www.metropolegrandparis.fr/fr/content/la-metropole-et-ses-competences).

${ }^{62}$ See City of Toronto, "City of Toronto Act" (2006; online at https://www.toronto.ca/citygovernment/accountability-operations-customer-service/city-administration/city-managersoffice/intergovernmental-affairs/city-of-toronto-act/); Ontario Ministry of Municipal Affairs, Growth Plan for the Greater Golden Horseshoe (2017); Ontario Ministry of Municipal Affairs, "Provincial Policy Statement, 20I4" (2017; online at http://www.mah.gov.on.ca/PageI0679.aspx); Ontario Ministry of Municipal Affairs, "Updates to land use planning and appeal system" (20I7; online at http://www.mah.gov.on.ca/PageI766I.aspx); Province of Ontario, Greenbelt Plan (2017); Province of Ontario, Municipal Act, S.O. 200I, C. 25. 
${ }^{63}$ Lawrence J. Vale and Yonah Freemark, “The Privatization of American Public Housing: Leaving the Poorest of the Poor Behind," in K.B. Anacker, M.T. Nguyen, and D.P. Varady, eds., The Routledge Handbook of Housing Policy and Planning (Abingdon: Routledge), I89-206.

${ }^{64}$ Comparable data are not available for Toronto, but see below for a brief description.

${ }^{65}$ It is worth noting, of course, that in the Paris region the lack of social-housing concentration in the central city resulted in part from the fact that, as opposed to in many cities in the U.S., the center was historically seen as the more appealing area and many suburbs as the domain of the poor. Nevertheless, this story is incomplete, as Paris' suburbs represent a whole variety of economic circumstances (some wealthier than the city). Moreover, the central city has invested considerably in social housing in recent years, and the SRU law has required all suburban cities that are deficient on this front to do the same.

${ }^{66}$ Toronto data based on information acquired through the authors' email communication with officials from the Ontario Ministry of Housing in December 2018 about units funded through the Ontario Investment in Affordable Housing program.

${ }^{67}$ It should be noted that in many parts of the U.S., school districts are autonomous from municipal governments and frequently have districts that do not line up with the same boundaries as general-purpose governments.

${ }^{68}$ See Edbuild, "Fractured: The Accelerating Breakdown of America's School Districts" April, 20I9. Thirty states allow towns and neighborhoods to secede from their school districts and two states (Indiana and North Carolina) recently (2017) passed legislation to ease the process.

${ }^{69}$ Several recent French national reforms have attempted to reduce the discrepancy between communes based on property tax capacity. The taxe professsionnelle was eliminated in 20I0, removing the previously existing incentive to attract businesses (it was replaced with a revenue source distributed to higher-level entities, and less related to the presence of jobs in certain territories). This, however, encouraged cities to rely more on housing property taxes. In 2017, the national government eliminated the taxe d'habitation, which is housing-based property taxes, for most payers; one goal was to reduce the inequities produced by reliance on property taxes. The outcomes of these reforms have yet to be established, however. See Pierre Rondeau, "L'abandon de la taxe d'habitation est-il vraiment une bonne idée?” Slate, January I0, 20I8; Juliana Herman, “Canada’s approach to school funding," Center for American Progress (2013): May; and Ontario Ministry of Education, “Who's responsible for your child's education?” (July 3I, 2009; online at http://www.edu.gov.on.ca/eng/document/brochure/whosresp.html). 
${ }^{70}$ Wallace E. Oates, “The effects of property taxes and local public spending on property values: An empirical study of tax capitalization and the Tiebout hypothesis," Journal of Political Economy 77, no. 6 (I969): 957-97I; Paul Peterson, City Limits (Chicago: University of Chicago Press, I98I); and Charles M. Tiebout, “A Pure Theory of Local Expenditures," Journal of Political Economy 64, no. 5 (I956): 4I6-424.

71 Jonathan Schwartz, "Prisoners of Proposition I3: Sales Taxes, Property Taxes, and the Fiscalization of Municipal Land Use Decisions," Southern California Law Review 7I (1997): I83.

${ }^{72}$ See John Mollenkopf and Todd Swanstrom, “Explaining Ferguson Through Race and Place,” in Ingrid Gould Ellen and Justin Steil (eds), The Dream Revisited: Contemporary Debates About Housing, Segregation, and Opportunity, (New York: Columbia University Press, 20I9).

${ }^{73}$ Council taxes in the U.K. are paid directly by renters (instead of the landlord), but are still based on property valuation (online at https://www.thetenantsvoice.co.uk/advice_from_us/council-tax/).

${ }^{74}$ See City of Toronto, "Understanding the Toronto City Budget, 20I8" (20I7; online at https://www.toronto.ca/wpcontent/uploads/20I7/II/97f7-AI70XXXX_Budget_Basics_Understanding-final-web.pdf); French Direction Générale des Finances Publiques, “Quels sont les principaux impôts existant en France?” (20I8; online at https://www.impots.gouv.fr/portail/international-professionnel/questions/quels-sont-les-principaux-impots-existanten-france); French Government, “Quelles sont les ressources fiscales des collectivités?,” Vie publique (October 3I, 20I7; online at http://www.vie-publique.fr/decouverte-institutions/finances-publiques/collectivitesterritoriales/ressources/quelles-sont-ressources-fiscales-collectivites.html); and Mark Wingham, “Council Tax in London,” Working Paper 80, GLAEconomics (2017): January.

75 See FIPECO, "La péréquation des ressources entre les collectivités locales” (December 2, 20I6; online at https://www.fipeco.fr/pdf/o.44574500\%20I480688945.pdf); and French Government, “Qu'est-ce que la péréquation?," Vie publique (October 3I, 20I7; online at http://www.vie-publique.fr/decouverteinstitutions/finances-publiques/collectivites-territoriales/ressources/qu-est-ce-que-perequation.html).

${ }^{76}$ Martin, Lawrence L., and Jeannie Hock Schiff. “City-county consolidations: Promise versus performance.” State and local government review 43, no. 2 (20II): I67-I77.

${ }^{77}$ EdBuild 2019 (online at https://edbuild.org/content/fractured\#intro).

78 Trounstine, Segregation by Design. 
${ }^{79}$ See Benjamin K. Olson, “The Transportation Equity Act for the 2Ist Century: The Failure of Metropolitan Planning Organizations to Reform Federal Transportation Policy in Metropolitan Areas," Transportation Law Journal 28 (2000-200I): I47; James F. Wolf and Mary Beth Farquhar, “Assessing Progress: The State of Metropolitan Planning Organizations under ISTEA and TEA-2I," International Journal of Public Administration 28, no. I3-I4 (2005): I057-I079; and Gian-Claudia Sciara, "Metropolitan Transportation Planning: Lessons from the Past, Institutions for the Future," Journal of the American Planning Association 83, no. 3 (2017): 262-276.

${ }^{80}$ Orfield, American Metropolitics; and Margaret Weir, “Coalition building for regionalism,” in Bruce Katz (ed.), Reflections on Regionalism (Washington: The Brookings Institution, 2000): I27-I53.

${ }^{81}$ Rusk, Cities without Suburbs.

${ }^{82}$ Daniel Kübler and Michael A. Pagano, "Urban politics as multilevel analysis," in Karen Mossberger, Susan E.

Clarke, and Peter John (eds.), The Oxford Handbook of Urban Politics (Oxford: Oxford University Press, 20I2): II4I29; Elinor Ostrom, Governing the Commons: The Evolution of Institutions for Collective Action (New York: Cambridge University Press, 1990); and Margaret Weir, Jane Rongerude, and Christopher K. Ansell, “Collaboration is not enough: Vicious cycles of reform in Transportation Policy," Urban Affairs Review 44, no. 4 (2009): 455-489. ${ }^{83}$ The governance structure that was produced with the GLA encouraged mayors to focus on issues of planning and transport, with housing less prioritized. See Ben Worthy, Mark Bennister, and Max W. Stafford, "Rebels leading London: the mayoralties of Ken Livingstone and Boris Johnson compared," British Politics I4, no. I (2019): 23-43; and Ian Gordon, "Functional integration, political conflict and muddled metropolitanism in the London region: I850-20I6," in Alistair Cole and Renaud Payre (eds.), Cities as Political Objects, Cheltenham (2016): 3I-55.

${ }^{84}$ See Frédéric Gilli, “Paris metropole est-il un simple objet transitionnel?” Quaderni 73 (2010): 35-44.

${ }^{85}$ See "What is a housing benefit?" Shelter (2016): April 25

[http://england.shelter.org.uk/housing_advice/housing_benefit/what_is_housing_benefit].

${ }^{86}$ See Office of California Governor Gavin Newsom, “Governor Gavin Newsom Signs I8 Bills to Boost Housing Production," (October 9, 20I9; online at https://www.gov.ca.gov/2019/Io/o9/governor-gavin-newsom-signs-I8-billsto-boost-housing-production/); and Laura Bliss, "California’s New Governor Would Punish Cities Over Affordable Housing," CityLab (January II, 20I9).

${ }^{87}$ See Laurel Wamsley, “Oregon Legislature Votes to Essentially Ban Single-Family Zoning,” NPR News (July I, 2019; online at https://www.npr.org/2019/07/oI/737798440/oregon-legislature-votes-to-essentially-ban-single-family- 
zoning). Cities and states examining the potential for upzoning should proceed carefully so as to ensure that lowincome families are not priced out by increased property values; see Yonah Freemark, "Upzoning Chicago: Impacts of a Zoning Reform on Property Values and Housing Construction," Urban Affairs Review, online pre-print (2019).

${ }^{88}$ It is worth noting that, in some cases, real-estate interests support affordable housing mandates (such as in Massachusetts), because it offers them an avenue for more development in general through mixed-income projects. Margaret Weir, "Planning, Environmentalism, and Urban Poverty: The Political Failure of National Land Use Planning Legislation, I970-1975," in Robert Fishman (ed.), The American Planning Tradition: Culture and Policy (Washington: Woodrow Wilson Center Press, 2000): 193-215.

${ }^{89}$ Nestor Davidson, Richard Briffault, Paul A. Diller, and Olatunde Johnson, The Troubling Turn in State Preemption: The Assault on Progressive Cities and How Cities Can Respond, September J. ACS Briefs 3 (20I7) 


\section{Author biographies}

Yonah Freemark (freemark@mit.edu; ORCID 0000-0003-3622-6354) is a doctoral candidate in the Department of Urban Studies and Planning at the Massachusetts Institute of Technology.

Justin Steil (steil@mit.edu; ORCID o0oo-0003-I76I-655X) is Associate Professor of Law and Urban Planning in the Department of Urban Studies and Planning at the Massachusetts Institute of Technology.

Kathleen Thelen (kthelen@mit.edu; ORCID o000-0003-4I02-8504) is Ford Professor of Political Science in the Department of Political Science at the Massachusetts Institute of Technology. 


\section{Appendix A: Summary of land-use powers in metropolitan areas evaluated}

\begin{tabular}{|c|c|c|c|c|c|}
\hline & London & Paris & Toronto & Boston & San Francisco \\
\hline Zoning power & $\begin{array}{l}\text { Boroughs control } \\
\text { use classes and } \\
\text { building permits } \\
\text { with discretionary } \\
\text { review. GLA Mayor } \\
\text { oversees all major } \\
\text { projects, which must } \\
\text { comply with GLA's } \\
\text { London Plan. } \\
\text { Appeals go through } \\
\text { national Planning } \\
\text { Inspectorate }\end{array}$ & $\begin{array}{l}\text { Land use is } \\
\text { determined by } \\
\text { municipal } \\
\text { governments, but will } \\
\text { be transferred to } \\
\text { Métropole eventually. } \\
\text { Land use must } \\
\text { comply with regional } \\
\text { plan and national } \\
\text { affordable housing } \\
\text { and climate change } \\
\text { requirements. } \\
\text { Enforced by prefect. }\end{array}$ & $\begin{array}{l}\text { Municipalities } \\
\text { control land use. } \\
\text { Local plans must } \\
\text { accord with } \\
\text { provincial plans, } \\
\text { which require } \\
\text { minimum densities } \\
\text { and identify } \\
\text { developable land. } \\
\text { Plans and zoning } \\
\text { can be appealed to } \\
\text { provincial Planning } \\
\text { Appeal Tribunal. }\end{array}$ & $\begin{array}{l}\text { Municipalities control } \\
\text { zoning. }\end{array}$ & $\begin{array}{l}\text { Municipalities } \\
\text { control zoning, in } \\
\text { compliance with } \\
\text { some state level } \\
\text { planning goals and } \\
\text { requirements. }\end{array}$ \\
\hline $\begin{array}{l}\text { Development } \\
\text { capacity }\end{array}$ & $\begin{array}{l}\text { GLA controls major } \\
\text { redevelopment } \\
\text { projects. National } \\
\text { government } \\
\text { establishes urban } \\
\text { development } \\
\text { corporations and } \\
\text { their boards. }\end{array}$ & $\begin{array}{l}\text { Redevelopment } \\
\text { authority and eminent } \\
\text { domain primarily } \\
\text { held by Métropole } \\
\text { and its subentities. } \\
\text { National government } \\
\text { can occasionally } \\
\text { designate major } \\
\text { projects for } \\
\text { redevelopment. Cities } \\
\text { can also develop } \\
\text { projects through } \\
\text { mixed-economy } \\
\text { public corporations } \\
\text { (SEMs). }\end{array}$ & & $\begin{array}{l}\text { Boston Planning and } \\
\text { Development Agency } \\
\text { plays a major } \\
\text { development role for } \\
\text { large sites; similar } \\
\text { agencies exist in } \\
\text { some other } \\
\text { municipalities. } \\
\text { Redevelopment is led } \\
\text { primarily by the } \\
\text { private sector. }\end{array}$ & $\begin{array}{l}\text { California abolished } \\
\text { local redevelopment } \\
\text { agencies in 20II. San } \\
\text { Francisco Office of } \\
\text { Economic and } \\
\text { Workforce } \\
\text { Development plays } \\
\text { role in coordinating } \\
\text { public-private } \\
\text { development, but } \\
\text { private sector leads } \\
\text { development. }\end{array}$ \\
\hline $\begin{array}{l}\text { Social/ } \\
\text { affordable } \\
\text { housing }\end{array}$ & $\begin{array}{l}\text { Boroughs and non- } \\
\text { profit housing } \\
\text { associations offer } \\
\text { social housing; } \\
\text { national government } \\
\text { provides entitlement } \\
\text { social housing } \\
\text { vouchers; GLA has } \\
\text { funds to provide } \\
\text { housing. GLA } \\
\text { London Plan } \\
\text { requires minimum } \\
\text { level of affordable } \\
\text { housing (currently } \\
35 \% \text { in new } \\
\text { projects. }\end{array}$ & $\begin{array}{l}\text { Region, cities, } \\
\text { counties, and non- } \\
\text { profits can fund new } \\
\text { social housing; } \\
\text { national government } \\
\text { provides entitlement } \\
\text { social housing } \\
\text { vouchers. National } \\
\text { government requires } \\
25 \% \text { social housing in } \\
\text { all cities of more than } \\
\text { I,50o residents by } \\
2025, \text { or cities will } \\
\text { face budget cuts. } \\
\text { National government } \\
\text { can override local } \\
\text { zoning to develop } \\
\text { new social housing. }\end{array}$ & $\begin{array}{l}\text { Province provides } \\
\text { funds for investment } \\
\text { in affordable } \\
\text { housing; much } \\
\text { funding from } \\
\text { national } \\
\text { government; no } \\
\text { entitlement } \\
\text { vouchers. Province } \\
\text { has given cities } \\
\text { ability to enforce } \\
\text { inclusionary zoning } \\
\text { if they desire. }\end{array}$ & $\begin{array}{l}\text { Cities have local } \\
\text { housing authorities, } \\
\text { with majority of } \\
\text { expenses funded by } \\
\text { national government. } \\
\text { State allocates } \\
\text { national tax credits to } \\
\text { developers to fund } \\
\text { subsidized housing. } \\
\text { No entitlement } \\
\text { vouchers. } \\
\text { Inclusionary } \\
\text { requirements vary by } \\
\text { city; Boston requires } \\
\text { I3\% of units in new } \\
\text { buildings with Io or } \\
\text { more units requesting } \\
\text { a zoning change to be } \\
\text { affordable. State law } \\
\text { allows affordable } \\
\text { housing developers to } \\
\text { appeal denial of } \\
\text { zoning approval if } \\
\text { IO\% of housing in } \\
\text { municipality is not } \\
\text { already affordable. }\end{array}$ & $\begin{array}{l}\text { Cities have local } \\
\text { housing authorities, } \\
\text { with majority of } \\
\text { expenses funded by } \\
\text { national government. } \\
\text { State allocates } \\
\text { national tax credits to } \\
\text { developers to fund } \\
\text { subsidized housing. } \\
\text { No entitlement } \\
\text { vouchers. San } \\
\text { Francisco requires } \\
\text { developers of new } \\
\text { buildings with Io or } \\
\text { more units requesting } \\
\text { a zoning change to } \\
\text { make contribution to } \\
\text { affordable housing. }\end{array}$ \\
\hline
\end{tabular}




\section{Appendix B: Summary of taxation and redistribution in metropolitan areas evaluated}

\begin{tabular}{|c|c|c|c|c|c|}
\hline & London & Paris & Toronto & Boston & San Francisco \\
\hline Property taxes & $\begin{array}{l}\text { Boroughs and } \\
\text { GLA control } \\
\text { property tax rates } \\
\text { for residential and } \\
\text { commercial } \\
\text { property. }\end{array}$ & $\begin{array}{l}\text { Municipalities } \\
\text { control property } \\
\text { tax rates (though } \\
\text { tax on housing } \\
\text { property is being } \\
\text { phased out). }\end{array}$ & $\begin{array}{l}\text { Municipalities } \\
\text { control property } \\
\text { tax rate. }\end{array}$ & $\begin{array}{l}\text { Municipalities } \\
\text { control property } \\
\text { tax rate, but there } \\
\text { is a state-imposed } \\
\text { cap and a limit on } \\
\text { increases. }\end{array}$ & $\begin{array}{l}\text { Municipalities } \\
\text { control property } \\
\text { tax rate, but there } \\
\text { is a state-imposed } \\
\text { cap and a limit on } \\
\text { increases. Taxes } \\
\text { assessed based on } \\
\text { purchase value, } \\
\text { not current value. }\end{array}$ \\
\hline Sales taxes & No direct power. & No direct power. & No direct power. & $\begin{array}{l}\text { Localities can } \\
\text { impose sales taxes } \\
\text { only on meals (up } \\
\text { to } 0.75 \% \text { ) and } \\
\text { lodging (up to } \\
6.5 \% \text { ). }\end{array}$ & $\begin{array}{l}\text { Every county in } \\
\text { California has } \\
\text { adopted maximum } \\
\text { allowable I\% sales } \\
\text { tax, Localities can } \\
\text { levy up to I\% } \\
\text { additional tax with } \\
\text { voter approval. }\end{array}$ \\
\hline Income taxes & No direct power. & $\begin{array}{l}\text { Payroll tax } \\
\text { imposed for } \\
\text { regional } \\
\text { transportation. }\end{array}$ & No direct power. & No direct power. & $\begin{array}{l}\text { No direct power, } \\
\text { except San } \\
\text { Francisco, limited } \\
\text { payroll taxes. }\end{array}$ \\
\hline $\begin{array}{l}\text { Additional taxes } \\
\text { (not including } \\
\text { service fees) }\end{array}$ & $\begin{array}{l}\text { GLA imposes } \\
\text { Community } \\
\text { Infrastructure } \\
\text { Levy-tax on new } \\
\text { development. }\end{array}$ & $\begin{array}{l}\text { Region raises } \\
\text { funds from car } \\
\text { registration, } \\
\text { parking spaces, } \\
\text { office space. }\end{array}$ & $\begin{array}{l}\text { Municipalities } \\
\text { impose land } \\
\text { transfer tax. }\end{array}$ & $\begin{array}{l}\text { Municipalities } \\
\text { obtain revenues } \\
\text { from motor vehicle } \\
\text { taxes, licenses, } \\
\text { permits, fees, } \\
\text { fines, linkage fees } \\
\text { on new } \\
\text { commercial } \\
\text { developments. }\end{array}$ & $\begin{array}{l}\text { Municipalities } \\
\text { obtain revenues } \\
\text { from motor } \\
\text { vehicle taxes, } \\
\text { licenses, permits, } \\
\text { fees, fines, and } \\
\text { development } \\
\text { impact fees. }\end{array}$ \\
\hline $\begin{array}{l}\text { Redistribution } \\
\text { between } \\
\text { governments }\end{array}$ & $\begin{array}{l}\text { GLA transfers a } \\
\text { share of revenues } \\
\text { from commercial } \\
\text { property taxes to } \\
\text { other local } \\
\text { governments in } \\
\text { U.K. Boroughs } \\
\text { receive } 6 \mathrm{I} \% \text { of } \\
\text { budgets from } \\
\text { national } \\
\text { government } \\
\text { transfers. }\end{array}$ & $\begin{array}{l}\text { National } \\
\text { government } \\
\text { imposes horizontal } \\
\text { transfers between } \\
\text { cities and counties. } \\
\text { Métropole } \\
\text { redistributes funds } \\
\text { through its budget. }\end{array}$ & $\begin{array}{l}\text { Property tax } \\
\text { revenues for } \\
\text { schools are } \\
\text { adjusted and } \\
\text { equalized by } \\
\text { province. Both } \\
\text { Toronto and York } \\
\text { region receive } \mathrm{I} 7 \% \\
\text { of operating } \\
\text { budgets from } \\
\text { Ontario } \\
\text { government. }\end{array}$ & \begin{tabular}{|l|} 
Limited federal, \\
state redistribution. \\
For City of Boston, \\
$\mathrm{I} 4 \%$ of annual \\
revenue from state \\
transfers, primarily \\
for education; $5 \%$ \\
from federal \\
transfers. Local \\
property taxes \\
provide $70 \%$ of \\
Boston revenue.
\end{tabular} & $\begin{array}{l}\text { Limited federal } \\
\text { and state } \\
\text { redistribution. For } \\
\text { the City of San } \\
\text { Francisco, } \\
\text { approximately } 8 \% \\
\text { of annual revenues } \\
\text { come from state } \\
\text { transfers and } 6 \% \\
\text { from federal } \\
\text { transfers. }\end{array}$ \\
\hline
\end{tabular}




\section{Appendix C: Mechanisms to hoard resources through fragmentation-or limit it}

\begin{tabular}{|c|c|c|c|c|c|}
\hline & \multicolumn{3}{|c|}{ Resource hoarding opportunity } & \multicolumn{2}{|l|}{ Opposing resource hoarding } \\
\hline & Mechanism & Consequence & Practitioner(s) & Mechanism(s) & Practitioner(s) \\
\hline \multirow{5}{*}{ 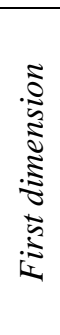 } & \multirow{5}{*}{$\begin{array}{l}\text { (1) Incorporation } \\
\text { of suburban areas }\end{array}$} & \multirow{5}{*}{$\begin{array}{l}\text { Limits potential } \\
\text { redistribution of } \\
\text { revenues from a } \\
\text { broad tax base }\end{array}$} & \multirow{5}{*}{ Boston region } & Incorporate all land & London, Paris \\
\hline & & & & $\begin{array}{l}\text { Require higher-level agreement for } \\
\text { incorporation }\end{array}$ & Toronto (2001) \\
\hline & & & & Require municipal mergers & $\begin{array}{l}\text { London (1999), } \\
\text { Toronto (1997) }\end{array}$ \\
\hline & & & & Encourage municipal mergers & Paris (2015) \\
\hline & & & & Annexation of surrounding land & $\begin{array}{l}\text { Houston, } \\
\text { similar regions }\end{array}$ \\
\hline \multirow{10}{*}{ 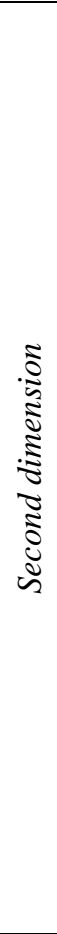 } & \multirow{4}{*}{$\begin{array}{l}\text { (2) Exclusion: Do } \\
\text { nothing to provide } \\
\text { affordable } \\
\text { housing }\end{array}$} & \multirow{4}{*}{$\begin{array}{l}\text { Makes } \\
\text { jurisdictions } \\
\text { off-limits for } \\
\text { low-income } \\
\text { households }\end{array}$} & \multirow{4}{*}{$\begin{array}{l}\text { Many } \\
\text { jurisdictions in } \\
\text { Boston, San } \\
\text { Francisco } \\
\text { regions }\end{array}$} & $\begin{array}{l}\text { Allow national government to override } \\
\text { zoning and to develop affordable } \\
\text { housing directly }\end{array}$ & Paris (2013) \\
\hline & & & & $\begin{array}{l}\text { As-of-right affordable housing } \\
\text { vouchers }\end{array}$ & Paris, London \\
\hline & & & & $\begin{array}{l}\text { Require all cities to achieve a certain } \\
\text { level of affordable housing or face fines } \\
\text { that are redistributed to other cities }\end{array}$ & Paris (2000) \\
\hline & & & & $\begin{array}{l}\text { Allow affordable housing developers to } \\
\text { sue to be allowed to build }\end{array}$ & Boston (1969) \\
\hline & \multirow{3}{*}{$\begin{array}{l}\text { (3) Municipal } \\
\text { parochialism and } \\
\text { fiscal competition: } \\
\text { Rely on property } \\
\text { taxes to fund local } \\
\text { public services }\end{array}$} & \multirow{3}{*}{$\begin{array}{l}\text { Encourages } \\
\text { jurisdictions to } \\
\text { attract uses that } \\
\text { can pay more in } \\
\text { property taxes }\end{array}$} & \multirow{3}{*}{$\begin{array}{l}\text { Boston, San } \\
\text { Francisco } \\
\text { regions }\end{array}$} & Equalize tax levels across jurisdictions & Toronto (1998) \\
\hline & & & & $\begin{array}{l}\text { Redistribute revenues at the } \\
\text { metropolitan level }\end{array}$ & Paris (2013) \\
\hline & & & & $\begin{array}{l}\text { Provide services at the national or } \\
\text { metropolitan levels }\end{array}$ & $\begin{array}{l}\text { London, Paris, } \\
\text { Toronto }\end{array}$ \\
\hline & \multirow{3}{*}{$\begin{array}{l}\text { (4) Exclusion and } \\
\text { fiscal competition: } \\
\text { Only allow } \\
\text { certain land uses, } \\
\text { especially large- } \\
\text { lot single-family } \\
\text { homes }\end{array}$} & \multirow{3}{*}{$\begin{array}{l}\text { Encourages } \\
\text { only high- } \\
\text { income } \\
\text { households to } \\
\text { live in certain } \\
\text { jurisdictions }\end{array}$} & \multirow{3}{*}{$\begin{array}{l}\text { Many } \\
\text { jurisdictions in } \\
\text { Boston, San } \\
\text { Francisco } \\
\text { regions }\end{array}$} & $\begin{array}{l}\text { Require zoning to meet regional or } \\
\text { national goals }\end{array}$ & $\begin{array}{l}\text { London, Paris, } \\
\text { Toronto }\end{array}$ \\
\hline & & & & $\begin{array}{l}\text { Simplify appeals for zoning decisions } \\
\text { that do not meet goals }\end{array}$ & $\begin{array}{l}\text { London, } \\
\text { Toronto }\end{array}$ \\
\hline & & & & $\begin{array}{l}\text { Allow regional or national entities to } \\
\text { declare major developments in public } \\
\text { interest and override plans }\end{array}$ & London, Paris \\
\hline
\end{tabular}

